\title{
Salt marshes as nurseries for nekton: testing hypotheses on density, growth and survival through meta-analysis
}

\author{
Thomas J. Minello ${ }^{1, *}$, Kenneth W. Able ${ }^{2}$, Michael P. Weinstein ${ }^{3}$, Cynthia G. Hays ${ }^{4}$ \\ ${ }^{1}$ National Marine Fisheries Service, Southeast Fisheries Science Center, Galveston Laboratory, 4700 Avenue U, Galveston, \\ Texas 77551, USA \\ ${ }^{2}$ Institute of Marine and Coastal Sciences, Rutgers University, 800 Great Bay Boulevard, Tuckerton, New Jersey 08087, USA \\ ${ }^{3}$ New Jersey Marine Sciences Consortium, Sandy Hook Field Station, Building 22, Fort Hancock, New Jersey 07732, USA \\ ${ }^{4}$ Department of Biology, University of California, 225 Sinsheimer, Santa Cruz, California 95064, USA
}

\begin{abstract}
We examined the nursery role of salt marshes for transient nekton by searching the literature for data on density, growth, and survival of juvenile fishes and decapod crustaceans in marshes and using meta-analyses to test hypotheses. We analyzed density data from 32 studies conducted throughout the world. Based on fish density, habitat types could be ranked from highest to lowest as: seagrass > vegetated marsh edge, nonvegetated marsh, open water, macroalgae, oyster reefs > vegetated inner marsh. However, patterns of habitat use varied among the 29 fish species represented. For decapod crustaceans (seven species), habitat types were ranked: seagrass > vegetated marsh edge $>$ nonvegetated marsh, vegetated inner marsh, open water, macroalgae $>$ oyster reef. We identified only 5 comparative studies on transient nekton growth in salt marshes. Fish growth in nonvegetated salt marsh was not significantly different from growth in open water or in macroalgae beds but was significantly lower than in seagrass. Growth of decapod crustaceans was higher in vegetated marsh than in nonvegetated marsh. Nekton survival in salt marsh (11 studies analyzed) was higher than in open water, lower than in oyster reef/cobble and not significantly different from survival in seagrass. When density, growth and survival are all considered, the relative nursery value of salt marshes for nekton appears higher than open water but lower than seagrass. Vegetated marsh appears to have a higher nursery value than nonvegetated marsh; however, tidal dynamics and nekton movement among marsh components complicates these comparisons. The available data have a strong geographical bias; most studies originated in the northern Gulf of Mexico or on the Atlantic coast of the United States. This bias may be significant because there is some evidence that salt marsh nursery value is dependent on geography, salinity regimes and tidal amplitude.
\end{abstract}

KEY WORDS: Salt marshes · Nekton · Meta-analysis · Decapod crustaceans · Habitat $\cdot$ Seagrass

\section{INTRODUCTION}

Salt marshes are considered nurseries for many nekton species but the nursery concept itself has not been clearly or consistently defined. Beck et al. (2001) proposed that 'a habitat is a nursery for juveniles of a particular species if its contribution per unit area to the production of individuals that recruit to adult populations is greater, on average, than production from other habitats in which juveniles occur'. They recognized that production reaching adult populations is dependent on a combination of processes including: (1) successful recruitment to juvenile habitats; (2) adequate growth in these habitats; and (3) adequate survival both within juvenile habitats and during the migration to adult spawning habitats. The density of juveniles reflects recruitment, mortality and emigration; thus, density can be an important indicator of nursery habitat value (Minello 1999). Following the definition of Beck et al. (2001), we only apply the nursery concept to 
species that have separate juvenile and adult habitats, or habitats that are not completely overlapping.

Just as the term nursery can be confusing in marine ecological literature, other terms related to nekton use of salt marsh habitats also need clarification. The term 'habitat' has been used generally to mean a location where animals live, with the boundaries of the area defined by an author (rather than the animal) based on structure, plants or physicochemical descriptors. These areas usually support recognizable communities identified by their dominant components, such as coral reefs, seagrass beds, salt marshes, mangroves or oyster reefs. Whitaker et al. (1973) referred to these community habitats as biotopes. In general ecological literature, however, the 'habitat' of a species is the place where a population of that species (or life stage) lives at any particular time (Odum 1971, Whitaker \& Levin 1975, Baltz 1990, Peters \& Cross 1992, Ricklefs 1973); and often this habitat (defined by the animal) encompasses more than 1 biotope. Using the terms habitat and biotope interchangeably may be convenient but can cause confusion when the habitat of a particular species is considered. Herein, we use the term habitat to include all of the places that a life stage of a species lives; we use the term biotope to indicate a community habitat as in Whitaker et al. (1973). We use 'habitat type' generically to describe any particular place that organisms live. Thus, a species has an adult habitat, a juvenile habitat and a nursery habitat (a nursery habitat is a subset of a juvenile habitat); and all of these habitats may include many different biotopes and habitat types. We also broadly define nekton in this paper as organisms that are free swimming at some time in their life cycle. This usage allowed the inclusion of relatively benthic forms such as lobsters.

Salt marshes are generally recognized as areas that include intertidal, emergent, vascular plants, but a more specific definition is needed when making comparisons between marshes and other habitat types. We define a salt marsh as a complex that includes the vegetated marsh surface, marsh ponds and pools, intertidal creeks, and subtidal creeks. In the literature, salt marshes have been defined both broadly (e.g Rountree \& Able 1992, Deegan et al. 2000) and narrowly (e.g. Teal 1962, Kneib 2000); however, the broad definition acknowledges that nekton move among these marsh components at high tide and generally must move off the vegetated marsh surface at low tide (but see Kneib 1984, 1997a). The inherently different components of salt marshes and the different salt marsh definitions in use, have complicated comparisons of marshes with other biotopes.

In this review and meta-analysis, we examine the value of salt marshes as nurseries using the definition of Beck et al. (2001) and our broad definition of a salt marsh. We divide salt marshes into 6 different components including 2 types of vegetated marsh (vegetated marsh edge and vegetated inner marsh) and 4 types of nonvegetated marsh (nonvegetated marsh edge, marsh pools and ponds, intertidal creeks and subtidal creeks). These terms and others are defined in the glossary (see Appendix 1). We test the hypotheses that the nursery value of different marsh components is similar and that the nursery value of the salt marsh is similar to that of other biotopes, such as seagrass beds and open water. The paper focuses on density, growth and survival in juvenile habitats as well as on motile invertebrates and fishes with complex life cycles in which larvae are transported to estuaries from coastal waters and live in salt marshes.

\section{MATERIALS AND METHODS}

Our intent was to review all available data on density, growth and survival of transient nekton in salt marshes worldwide. We searched our personal databases along with Aquatic Science and Fisheries Abstracts (Cambridge Scientific Abstracts, Bethesda, MD) and Current Contents/Agriculture, Biology \& Environmental Sciences (ISI, Philadelphia, PA) for literature on abundance, growth and survival of nekton in salt marshes and found 800 to 900 potential studies for analysis. Most of these studies, however, were eliminated upon further examination with regard to our final selection criteria. We excluded studies with data solely on marsh resident species, because our nursery criteria requires that juvenile and adult habitats do not completely overlap. We excluded studies that did not provide a comparison of nursery functions either among salt marsh components or between one or more salt marsh component and another biotope. Because sampling limitations affect abundance comparisons in shallow water habitats (Kneib 1997b, Rozas \& Minello 1997, Connolly 1999, Minello 1999), we only included such studies if nekton densities (animals per area of bottom) were reported. For example, we included data from enclosure samplers (e.g. drop samplers, throw traps, Wegener rings, lift nets, flume weirs) where the sampling area was reported but did not include data from sampling gear where the area sampled was not specified (mainly trawls, seines, gill nets, traps). If data from towed nets were reported as animals per area swept, we considered these density estimates. We excluded study results if measurements of nursery function could not be associated with our particular marsh habitat types. For estimates of survival or mortality, we only included studies where mortality could be separated from population losses due to emigration. 
We assigned density values to our different habitat types based on information available in each paper; however, there may have been errors in this classification. The misidentification of habitat types is most likely between nonvegetated marsh and open water and among nonvegetated marsh types. We considered open water to be estuarine areas not within a salt marsh complex, including areas within open bays, inlets, coves, bayous, large subtidal channels and coastal lakes. Open water areas are not surrounded by salt marsh vegetation or are large enough ( $>$ several $\mathrm{km}$ in diameter) for the direct influence of marsh vegetation on nekton to be minimal. Within a salt marsh complex, we considered areas of nonvegetated bottom within approximately $10 \mathrm{~m}$ of marsh vegetation as nonvegetated marsh edge. This definition is tenuous and may overlap with open water or with other nonvegetated marsh categories, such as pools and ponds and intertidal creeks. See the glossary for additional definitions of habitat types (Appendix 1).

For each study, we recorded the species examined, the year and season of sampling, the location including latitude and longitude, the habitat types examined in addition to salt marsh, the method of data collection, the salinity regime and the tidal range. We classified study locations into the following salinity regimes: oligohaline (salinity between 0.5 and $5 \mathrm{ppt}$ ), mesohaline (5 to $18 \mathrm{ppt}$ ), and polyhaline (>18 ppt). If tidal range was not reported, we used the difference between mean low water and mean high water from the nearest US National Oceanic and Atmospheric Administration tide gauge to represent tidal range.

We developed databases on density, growth and survival that included mean values, standard deviations (SDs) and the number of observations. The number of independent comparisons between habitat types from any study (i.e. the number of rows in the database) was determined by the number of nekton species included, the number of habitat types examined and by certain subjective decisions on the independence of data. These decisions on the number of independent observations are important because they affect analytical power and the influence of a particular study on the overall analysis. Within a study, we considered data from different seasons and years to be independent. In the northern hemisphere, spring samples were those collected in March, April and May; summer in June, July and August; fall in September, October and November; and winter in December, January and February. The treatment of spatial (i.e. location or site) differences was based on the original author's analysis, and we considered locations to be independent if they were reported as such in the study. In some instances, values had to be estimated from figures or graphs. Infrequently, we also had to calculate SDs from sea- sonal or spatial replicates presented. If we could not obtain an estimate of the SD or number of observations, the data were not included in our analyses. When data had to be combined, we use unweighted means and calculated a pooled standard deviation (Topping 1962).

We conducted meta-analyses using MetaWin 2.0 (Sinauer Associates 1997, Rosenberg et al. 2000) and used Hedges' $d$ (Hedges \& Olkin 1985) as the metric to measure effect size. Hedges' $d$ requires a mean, a SD and the number of observations for each value compared and is calculated as:

$$
d=\frac{\left(\bar{X}^{e}-\bar{X}^{c}\right)}{S} J
$$

where $\mathrm{S}$ is the pooled $\mathrm{SD}, \bar{X}^{\mathrm{e}}$ and $\bar{X}^{\mathrm{c}}$ are the means of the experimental and control groups, respectively and

$$
J=1-\frac{3}{4\left(N^{c}+N^{e}-2\right)-1}
$$

where $N^{c}$ and $N^{\mathrm{e}}$ are the numbers of observations in the control and experimental groups, respectively. Therefore, $d$ describes the difference between an experimental and control group in terms of SD units. Thus, a positive value of $d$ in our analyses reflects greater density, growth or survival of nekton in the experimental habitat type compared with the control habitat type. For growth, survival and one of our density analyses, salt marsh was the experimental habitat type and other biotopes (e.g. seagrass, open water) were the control. We also developed a second density database for meta-analysis that only included marsh data. In this analysis, vegetated marsh was the experimental group and nonvegetated marsh was the control.

Hedges' $d$ was calculated for all habitat comparisons in the data sets and a weighted average effect size (E) was determined. Confidence intervals for these cumulative effect sizes were generated using bootstrapping methods (999 iterations) and used to test for significant differences from 0 with $\alpha=0.05$. Confidence intervals generated through randomization techniques are considered more conservative than parametric methods, and there is no underlying assumption about normality of the data (Rosenberg et al. 2000). However, bootstrap confidence intervals do assume that the distribution of bootstrapped values is centered around the original mean value; we used bias-corrected bootstrap confidence intervals to ameliorate any bias due to small sample sizes (Efron 1987, Rosenberg et al. 2000).

In addition to estimating the cumulative or overall effect size across studies, MetaWin 2.0 also calculates $Q_{t}$, a measure of the variation in effect sizes for a set of studies (total heterogeneity). $\mathrm{Q}_{\mathrm{t}}$ is a weighted sum of 
squares and is analogous to the total sum of squares in an analysis of variance (Rosenberg et al. 2000). Similar to analysis of variance, $Q_{t}$ can be partitioned in categorical or classified analyses into the variance in effect sizes between class variables $\left(Q_{b}\right)$; comparisons of $Q_{b}$ with the residual variance can then be used to test whether effect sizes are similar among the class variables. We ran categorical random-effects models to compare effect sizes among various habitat types and made specific habitat comparisons by conducting categorical analyses on subsets of the data. We also examined continuous models where we calculated a weighted least-squares regression between effect size and the continuous variables of latitude and tidal range.

\section{RESULTS}

\section{Density}

Thirty-two studies comparing nekton densities among habitat types met our criteria for analysis (Table 1). Most of the studies were conducted on the northern coast of the Gulf of Mexico (22) and more than half of these were conducted in the Galveston Bay system of Texas. An additional 8 studies were conducted on the Atlantic coast of the United States from Connecticut to South Carolina. Thus, $94 \%$ of the studies included in our analysis of nekton densities were conducted in the US. Outside of the US., one study was conducted in

Table 1. List of studies included in the 2 meta-analyses on nekton density. The marsh versus marsh analysis compared different marsh components including vegetated edge (VE), vegetated inner (VI), nonvegetated edge (NVE), pools and ponds (PP), intertidal creeks (ITC) and subtidal creeks (STC). The marsh versus other analysis compared marsh and other biotopes including seagrass (SG), open water (OW), macroalgae (ALG) and oyster reefs (OR)

\begin{tabular}{|c|c|c|c|c|c|}
\hline Location & $\begin{array}{l}\text { Marsh vs } \\
\text { marsh }\end{array}$ & $\begin{array}{l}\text { Marsh vs } \\
\text { other }\end{array}$ & $\begin{array}{l}\text { Habitat types } \\
\text { compared }\end{array}$ & $\begin{array}{l}\text { Sampling } \\
\text { technique }\end{array}$ & Source \\
\hline \multicolumn{6}{|c|}{ Gulf coast, US } \\
\hline TX & & $\mathrm{X}$ & $\mathrm{OW}, \mathrm{SG}, \mathrm{VE}$ & Drop sampler & Rozas \& Minello (1998) \\
\hline TX & $\mathrm{X}$ & $\mathrm{X}$ & $\mathrm{SG}, \mathrm{NVE}, \mathrm{VE}$ & Drop sampler & Zimmerman et al. (1990c) \\
\hline TX & $\mathrm{X}$ & & NVE, PP, VE & Drop sampler & Zimmerman et al. (1990b) \\
\hline TX & & $\mathrm{X}$ & OW, SG, NVE & Sled, drop sampler & Petrik et al. (1999) \\
\hline TX & $\mathrm{X}$ & $\mathrm{X}$ & OR, OW, ITC, NVE, VE, VI & Sled, drop sampler, lift net & Stunz et al. (2002b) \\
\hline TX & & $\mathrm{X}$ & $\mathrm{OW}, \mathrm{SG}, \mathrm{VE}$ & Drop sampler & Thomas et al. (1990) \\
\hline TX & $\mathrm{X}$ & & NVE, VE, VI & Drop sampler & Minello \& Webb (1997) \\
\hline TX & $\mathrm{X}$ & $\mathrm{X}$ & OW, ITC, PP, VE, VI & Drop sampler & Rozas \& Zimmerman (2000) \\
\hline TX & $\mathrm{X}$ & $\mathrm{X}$ & SG, NVE, VE & Drop sampler & Zimmerman et al. (1990a) \\
\hline TX & & $\mathrm{X}$ & OW, VE & Drop sampler & Zimmerman et al. (1992) \\
\hline TX & $\mathrm{X}$ & $\mathrm{X}$ & OW, NVE, PP, VE, VI & Drop sampler & Minello et al. (1991) \\
\hline TX & $\mathrm{X}$ & & NVE, VE & Drop sampler & Zimmerman et al. (1984) \\
\hline TX & $\mathrm{X}$ & & NVE, VE & Drop sampler & Zimmerman \& Minello (1984b) \\
\hline TX & $\mathrm{X}$ & & NVE, VE & Drop sampler & Zimmerman et al. (1991) \\
\hline TX & $\mathrm{X}$ & $\mathrm{X}$ & OR, NVE, VE & Drop sampler & Zimmerman et al. (1989) \\
\hline LA & $\mathrm{X}$ & $\mathrm{X}$ & $\mathrm{SG}, \mathrm{NVE}, \mathrm{VE}$ & Throw trap & Castellanos \& Rozas (2001) \\
\hline LA & & $\mathrm{X}$ & OW, STC & Otter trawl & Deegan (1990) \\
\hline LA & $\mathrm{X}$ & $\mathrm{X}$ & SG, PP, VE & Drop sampler & Rozas \& Minello (1999) \\
\hline LA & $\mathrm{X}$ & & NVE, VE & Drop sampler & Zimmerman (1988) \\
\hline AL & & $\mathrm{X}$ & $\mathrm{SG}, \mathrm{VE}$ & Enclosure cylinder & Heck et al. (2001) \\
\hline AL & $\mathrm{X}$ & & NVE, VE & Drop sampler & Howe et al. (1999) \\
\hline $\mathrm{AL}$ & & $\mathrm{X}$ & OW, SG, VE & Drop sampler & Howe \& Wallace (2000) \\
\hline \multicolumn{6}{|c|}{ Atlantic coast, US } \\
\hline NJ, CT & & $\mathrm{X}$ & ALG, OW, SG, STC & Beam trawl & Goldberg et al. (2002) \\
\hline NJ & & $\mathrm{X}$ & ALG, OW, SG, STC & Suction sampler & Able et al. (1989) \\
\hline NJ & & $\mathrm{X}$ & ALG, OW, SG, STC & Drop sampler & Wilson et al. (1990b) \\
\hline NJ & & $\mathrm{X}$ & ALG, OW, SG, STC & Throw trap & Sogard \& Able (1991) \\
\hline VA & & $\mathrm{X}$ & SG, STC & Suction sampler & Orth \& Van Montfrans (1987) \\
\hline VA & & $\mathrm{X}$ & SG, STC & Otter trawl, Wegener ring & Weinstein \& Brooks (1983) \\
\hline VA & & $\mathrm{X}$ & OW, NVE, VE, VI & Drop sampler & Cicchetti (1998) \\
\hline $\mathrm{SC}$ & $\mathrm{X}$ & & STC, VE & Drop sampler & Mense \& Wenner (1989) \\
\hline \multicolumn{6}{|l|}{ Europe } \\
\hline The Nethe & lands & $\mathrm{X}$ & OW, ITC & Fyke net, beam trawl & Cattrijsse et al. (1997) \\
\hline \multicolumn{6}{|l|}{ Australia } \\
\hline Queenslan & $\mathrm{X}$ & & PP, VI & Pop net & Thomas \& Connally (2001) \\
\hline
\end{tabular}


Table 2. Comparison matrices for the meta-analysis of marsh versus marsh and marsh versus other habitat types. The number of independent comparisons is shown for each habitat type combination in the 2 analyses

\begin{tabular}{|c|c|c|c|c|c|}
\hline \multirow[t]{2}{*}{$\begin{array}{l}\text { Marsh vs marsh } \\
\text { Vegetated marsh }\end{array}$} & \multicolumn{4}{|c|}{ Nonvegetated marsh } & \multirow[t]{2}{*}{ Total } \\
\hline & Intertidal creeks & Nonvegetated edge & Pools and ponds & Subtidal creeks & \\
\hline Vegetated edge & 19 & 407 & 55 & 2 & 483 \\
\hline Vegetated inner & 19 & 18 & 23 & & 60 \\
\hline Total & 38 & 425 & 78 & 2 & 543 \\
\hline \multicolumn{6}{|l|}{ Marsh vs other } \\
\hline \multirow{2}{*}{ Marsh type } & \multicolumn{4}{|c|}{ Other habitat type } & Total \\
\hline & Open water & Seagrass & Macroalgae & Oyster reef & \\
\hline Intertidal creeks & 22 & 1 & & & 23 \\
\hline Nonvegetated edge & 10 & 150 & & 9 & 169 \\
\hline Pools and ponds & 18 & 4 & & & 22 \\
\hline Subtidal creeks & 29 & 38 & 32 & & 99 \\
\hline Vegetated edge & 77 & 175 & & 11 & 263 \\
\hline Vegetated inner & 31 & 4 & & & 35 \\
\hline Total & 187 & 372 & 32 & 20 & 611 \\
\hline
\end{tabular}

Europe (in the Westerschelde Estuary of The Netherlands) and one in South Queensland, Australia. Within salt marshes, most available comparisons were between vegetated marsh edge and nonvegetated marsh edge (Table 2). Most comparisons between salt marsh and other biotopes were with seagrass and open water.

In our initial density analysis, we included all nekton species and compared vegetated marsh (88.9\% marsh edge) with different types of nonvegetated marsh; $Q_{b}$ was significant, indicating that the effect size (E) differed among the nonvegetated marsh types (Table 3). Effect size was positive for nonvegetated edge and the $95 \%$ confidence interval did not overlap 0 (Table 3 ), indicating that overall nekton densities were significantly higher in vegetated marsh compared with nonvegetated edge. Densities in vegetated marsh were significantly lower than in subtidal creeks $(E=-0.63)$, but this result was based on only 2 comparisons from 1 study of portunid crab densities (143 animals) in South Carolina (Mense \& Wenner 1989). When compared with all nonvegetated marsh, the 2 types of vegetated marsh had significantly different effect sizes; densities in vegetated edge were higher than in nonvegetated marsh, while there was no significant difference between vegetated inner marsh and nonvegetated marsh (Table 3).

We also compared nekton densities in salt marshes with densities in other biotopes including open water, seagrass, macroalgae and oyster reef. For all nekton species combined, there was a significant difference among the effect sizes for these other biotopes; densities in salt marsh (all marsh components combined) were lower than in seagrass and higher than in oyster reef, while there was no significant difference between nekton densities in marsh and in open water or macroalgae (Table 4). The pattern was similar when only vegetated marsh was included in comparisons. However, when only nonvegetated marsh was included, there were no significant differences between salt marsh and either open water, macroalgae or oyster reef. We compared different salt marsh components with open water and found no significant differences in density between open water and nonvegetated marsh; however, densities in vegetated marsh were significantly higher than in open water (Table 4). In a similar comparison with seagrass, nekton densities in seagrass were significantly higher than all types of salt marsh examined.

Overall fish densities were not significantly different between vegetated marsh and nonvegetated marsh edge or marsh pools and ponds, but densities were lower in vegetated marsh than in intertidal creeks (Table 3). Fish densities in vegetated inner marsh were significantly lower than in nonvegetated marsh. In comparison with other biotopes, fish densities in salt marshes were significantly lower than in seagrass but not significantly different from densities in open water, macroalgae or oyster reef. Densities in open water were significantly higher than in vegetated inner marsh but not significantly different from densities in other marsh types (Table 4).

Our analyses on fish densities consolidated data on 29 species of transient fishes but density patterns varied among species (Table 5). In comparisons between vegetated and nonvegetated marsh, spotted seatrout Cynoscion nebulosus, striped mullet Mugil cephalus, pinfish Lagodon rhomboides and silver perch Bair- 
Table 3. Results of meta-analysis comparing nekton densities among different salt marsh types. A significant Q-value between marsh types $\left(Q_{b}\right)$ indicates that the effect size $(E)$ differs among the marsh types in that comparison. The effect size is based on Hedges' $d$ and a positive value indicates relatively high densities in the experimental marsh type (vegetated marsh) compared with the control marsh type (nonvegetated marsh). An effect is considered significant if the $95 \%$ confidence interval does not overlap 0. Abbreviations for marsh types are in Table 1

\begin{tabular}{|c|c|c|c|}
\hline \multirow{2}{*}{$\begin{array}{l}\text { Marsh type } \\
\text { All nekton species }\end{array}$} & $\begin{array}{l}\text { No. of } \\
\text { aparisc }\end{array}$ & $\mathrm{E}$ & \multirow[t]{2}{*}{$95 \% \mathrm{CI}$} \\
\hline & & & \\
\hline \multicolumn{4}{|c|}{$\begin{array}{l}\text { Compared to all vegetated marsh }(\mathrm{VE}, \mathrm{VI}) \\
\left(\mathrm{Q}_{\mathrm{b}}=16.52 ; \mathrm{p}=0.014 ; \mathrm{df}=3,542\right)\end{array}$} \\
\hline Nonvegetated edge & 425 & 0.458 & +0.350 to +0.568 \\
\hline Subtidal creeks & 2 & -0.633 & -0.880 to -0.632 \\
\hline Pools and ponds & 78 & 0.092 & -0.063 to +0.239 \\
\hline Intertidal creeks & 38 & -0.078 & -0.388 to +0.207 \\
\hline \multicolumn{4}{|c|}{$\begin{array}{l}\text { Compared to all nonvegetated marsh (NVE, PP, ITC, STC) } \\
\left(\mathrm{Q}_{\mathrm{b}}=12.75 ; \mathrm{p}=0.002 ; \mathrm{df}=1,542\right)\end{array}$} \\
\hline Vegetated edge & 483 & 0.419 & +0.329 to +0.516 \\
\hline Vegetated inner & 60 & -0.110 & -0.350 to +0.131 \\
\hline \multicolumn{4}{|l|}{ Fish } \\
\hline \multicolumn{4}{|c|}{$\begin{array}{l}\text { Compared to all vegetated marsh }(\mathrm{VE}, \mathrm{VI}) \\
\left(\mathrm{Q}_{\mathrm{b}}=21.11 ; \mathrm{p}=0.001 ; \mathrm{df}=2,321\right)\end{array}$} \\
\hline Nonvegetated edge & 256 & 0.009 & -0.068 to +0.075 \\
\hline Pools and ponds & 48 & -0.0 & -0.276 to +0.063 \\
\hline Intertidal creeks & 18 & -0.665 & -0.985 to -0.313 \\
\hline \multicolumn{4}{|c|}{$\begin{array}{l}\text { Compared to all nonvegetated marsh (NVE, PP, ITC, STC) } \\
\left(\mathrm{Q}_{\mathrm{b}}=12.28 ; \mathrm{p}=0.002 ; \mathrm{df}=1,321\right)\end{array}$} \\
\hline Vegetated edge & 289 & 0.005 & -0.065 to +0.085 \\
\hline Vegetated inner & 33 & -0.449 & -0.766 to -0.144 \\
\hline \multicolumn{4}{|l|}{ Decapod crustaceans } \\
\hline \multicolumn{4}{|c|}{$\begin{array}{l}\text { Compared to all vegetated marsh }(\mathrm{VE}, \mathrm{VI}) \\
\left(\mathrm{Q}_{\mathrm{b}}=18.39 ; \mathrm{p}=0.008 ; \mathrm{df}=3,220\right)\end{array}$} \\
\hline Nonvegetated edge & 169 & 0.958 & +0.814 to +1.112 \\
\hline Pools and ponds & 30 & 0.414 & +0.189 to +0.654 \\
\hline Subtidal creeks & 2 & -0.628 & -0.880 to -0.385 \\
\hline Intertidal creeks & 20 & 0.474 & +0.218 to +0.774 \\
\hline \multicolumn{4}{|c|}{$\begin{array}{l}\text { Compared to all nonvegetated marsh (NVE, PP, ITC, STC) } \\
\left(\mathrm{Q}_{\mathrm{b}}=8.52 ; \mathrm{p}=0.007 ; \mathrm{df}=1,220\right)\end{array}$} \\
\hline Vegetated edge & 194 & 1.031 & +0.855 to +1.231 \\
\hline Vegetated inner & 27 & 0.291 & +0.046 to +0.605 \\
\hline
\end{tabular}

diella chrysoura appeared to select vegetated marsh, while blackcheek tonguefish Symphurus plagiusa, gulf menhaden Brevoortia patronus, spot Leiostomus xanthurus, speckled worm eel Myrophis punctatus, Atlantic croaker Micropogonias undulatus and spotfin mojarra Eucinostomus argenteus selected nonvegetated marsh. In comparisons between vegetated marsh and open water, C. nebulosus, $M$. cephalus and $B$. chrysoura selected vegetated marsh, and $L$. xanthurus and $M$. undulatus selected open water. Red drum Sciaenops ocellatus and L. xanthurus had higher densities in nonvegetated marsh compared with open water, but
M. undulatus and winter flounder Pseudopleuronectes americanus had higher densities in open water. When significant density differences occurred, all fish species appeared to select seagrass over both vegetated and nonvegetated marsh. However, there were no significant differences in density between vegetated marsh and seagrass for some fish species, such as M. cephalus, L. xanthurus and L. rhomboides.

Density trends for decapod crustaceans were similar to those for overall nekton, but more comparisons were statistically significant. Within marshes, overall crustacean densities in vegetation were significantly higher than in nonvegetated edge, pools and ponds or intertidal creeks (Table 3). In addition, densities in vegetated edge were significantly higher than in vegetated inner marsh. In comparison with other biotopes, crustacean densities in salt marshes (all marsh components included) were significantly higher than in open water and oyster reef, and significantly lower than in seagrass (Table 4). When compared with open water, densities in vegetated marsh edge were significantly higher, but there were no significant differences with other marsh types. Crustacean densities in seagrass were significantly higher than in all marsh types.

Seven species of decapod crustaceans occurred in the database (Table 5); species with the greatest number of independent habitat comparisons included blue crab Callinectes sapidus, brown shrimp Farfantepenaeus aztecus (formerly Penaeus aztecus, see PerezFarfante \& Kensley 1997 for changes in shrimp nomenclature), white shrimp Litopenaeus setiferus (formerly Penaeus setiferus) and pink shrimp Farfantepenaeus duorarum (formerly Penaeus duorarum). Patterns of habitat use (based on density differences) were generally consistent among crustacean species (Table 5). All species selected for vegetated marsh over nonvegetated marsh and open water. Most species selected seagrass over both vegetated and nonvegetated marsh. However, there was no significant difference in densities of $F$. aztecus between seagrass and vegetated marsh, and densities of $L$. setiferus were not significantly different between seagrass and either vegetated marsh or nonvegetated marsh.

Differences in density patterns were apparent between the US Atlantic and Gulf of Mexico coasts. Along the Atlantic, fish densities in open water were significantly higher than in either vegetated or nonvegetated marsh, while no significant difference occurred in the Gulf (Table 6). Decapod crustacean densities on the Atlantic coast were not significantly different between vegetated marsh and open water, while densities in vegetated marsh were significantly higher than in open water on the Gulf coast. In addition, the general pattern of higher fish and crustacean densities in seagrass compared with vegetated 
marsh was stronger in the Atlantic compared with the Gulf.

We also examined density patterns in relation to salinity regimes and seasons. Although few strong interactions were apparent, habitat selection by fishes for seagrass (or submerged aquatic vegetation) over nonvegetated marsh did not occur in oligohaline areas of estuaries as it did in other salinity regimes (Table 6). The pattern of higher juvenile crustacean densities in vegetated marsh compared with nonvegetated marsh was more pronounced in polyhaline salinity regimes and in the summer.

Table 4. Results of meta-analysis comparing nekton densities between salt marsh and other biotopes. A significant Q-value between habitat types $(\mathrm{Qb})$ indicates that the effect size $(\mathrm{E})$ differs among the habitat types in that comparison. The effect size is based on Hedges' $d$, and a positive value indicates relatively high densities in the experimental habitat type (marsh) compared with the control habitat type (other biotopes). An effect is considered significant if the $95 \%$ confidence interval does not overlap 0. Abbreviations for habitat types are in Table 1

\begin{tabular}{|c|c|c|c|c|c|c|c|}
\hline Habitat type & $\begin{array}{l}\text { No. of } \\
\text { nparis }\end{array}$ & E & $95 \% \mathrm{CI}$ & \multicolumn{4}{|c|}{$\begin{array}{c}\text { No. of } \\
\text { comparisons }\end{array}$} \\
\hline \multicolumn{4}{|l|}{ All nekton species } & \multirow{2}{*}{\multicolumn{4}{|c|}{$\begin{array}{l}\text { Compared to open water } \\
\left(Q_{b}=12.65 ; p=0.031 ; d f=5,98\right)\end{array}$}} \\
\hline \multirow{2}{*}{\multicolumn{4}{|c|}{$\begin{array}{l}\text { Compared to all marsh types (VE, VI, NVE, PP, ITC, STC) } \\
\left(Q_{b}=64.38 ; p=0.001 ; d f=3,610\right)\end{array}$}} & & & & \\
\hline & & & & Subtidal creeks & 21 & -0.196 & -0.841 to +0.145 \\
\hline Macroalgae & 32 & -0.255 & -0.778 to +0.064 & Vegetated edge & 37 & +0.245 & -0.223 to +0.985 \\
\hline Open water & $\begin{array}{l}187 \\
372\end{array}$ & +0.189 & -0.016 to +0.388 & Nonvegetated edge & 6 & +0.026 & -1.463 to +1.471 \\
\hline $\begin{array}{l}\text { Seagrass } \\
\text { Oyster reef }\end{array}$ & $\begin{array}{r}372 \\
20\end{array}$ & $\begin{array}{l}-0.629 \\
+1.262\end{array}$ & $\begin{array}{l}-0.779 \text { to }-0.464 \\
+0.587 \text { to }+1.953\end{array}$ & Intertidal creeks & 10 & +0.878 & -0.130 to +1.989 \\
\hline Comnared toall yecre & & & & Vegetated inner & 17 & -0.901 & -1.634 to -0.260 \\
\hline $\begin{array}{l}\text { Compared to all vege } \\
\left(\mathrm{Q}_{\mathrm{b}}=39.64 ; \mathrm{p}=0.006\right.\end{array}$ & $\begin{array}{l}\text { etated } \\
6 ; \mathrm{df}=\end{array}$ & $\begin{array}{l}\operatorname{arsh}(\mathrm{VE} \\
297)\end{array}$ & & Pools and ponds & 8 & -0.364 & -1.548 to +0.164 \\
\hline Open water & 108 & +0.283 & -0.022 to +0.571 & \multirow{2}{*}{\multicolumn{4}{|c|}{$\begin{array}{l}\text { Compared to seagrass } \\
\left(Q_{b}=73.37 ; p=0.009 ; d f=3,205\right)\end{array}$}} \\
\hline Seagrass & 179 & -0.690 & -0.933 to -0.347 & & & & \\
\hline Oyster reef & 11 & +1.642 & +0.549 to +2.598 & Subtidal creeks & 26 & -0.292 & -0.781 to -0.058 \\
\hline \multirow{2}{*}{\multicolumn{4}{|c|}{$\begin{array}{l}\text { Compared to all nonvegetated marsh (NVE, PP, ITC, STC) } \\
\left(\mathrm{Q}_{\mathrm{b}}=25.16 ; \mathrm{p}=0.001 ; \mathrm{df}=3,312\right)\end{array}$}} & Vegetated edge & 90 & -0.521 & -0.781 to -0.213 \\
\hline & & & & Nonvegetated edge & 88 & -0.283 & -0.549 to -0.120 \\
\hline Macroalgae & 32 & -0.233 & -0.665 to +0.073 & Vegetated inner & 2 & -7.971 & -19.306 to -2.998 \\
\hline Open water & 79 & +0.060 & -0.201 to +0.270 & \multirow{2}{*}{\multicolumn{4}{|c|}{ Decapod crustaceans }} \\
\hline Seagrass & 193 & -0.582 & -0.756 to -0.436 & & & & \\
\hline Oyster reef & 9 & +0.793 & -0.125 to +1.535 & \multirow{2}{*}{\multicolumn{4}{|c|}{$\begin{array}{l}\text { Compared to all marsh types (VE, VI, NVE, PP, ITC, STC) } \\
\left(Q_{b}=62.30 ; p=0.001 ; d f=3,271\right)\end{array}$}} \\
\hline \multirow{2}{*}{\multicolumn{4}{|c|}{$\begin{array}{l}\text { Compared to open water } \\
\left(Q_{b}=23.22 ; p=0.002 ; d f=5,186\right)\end{array}$}} & & & & \\
\hline & & & & Macroalgae & 7 & -0.486 & -1.881 to +0.234 \\
\hline Subtidal creeks & 29 & -0.109 & -0.604 to +0.158 & Open water & 88 & +0.447 & +0.143 to +0.640 \\
\hline Vegetated edge & 77 & +0.620 & +0.331 to +0.941 & Seagrass & 165 & -0.822 & -1.050 to -0.529 \\
\hline $\begin{array}{l}\text { Nonvegetated edge } \\
\text { Intertidal creeks }\end{array}$ & $\begin{array}{l}10 \\
22\end{array}$ & $\begin{array}{l}-0.162 \\
+0.437\end{array}$ & $\begin{array}{l}-1.093 \text { to }+0.916 \\
-0.132 \text { to }+1.023\end{array}$ & Oyster reef & 12 & +1.467 & +0.542 to +2.133 \\
\hline Vegetated inner & 31 & -0.577 & -1.053 to -0.138 & \multirow{2}{*}{\multicolumn{4}{|c|}{$\begin{array}{l}\text { Compared to all nonvegetated marsh (NVE, PP, ITC, STC) } \\
\left(\mathrm{Q}_{\mathrm{b}}=48.87 ; \mathrm{p}=0.001 ; \mathrm{df}=3,124\right)\end{array}$}} \\
\hline Pools and ponds & 18 & -0.026 & -0.665 to +0.311 & & & & \\
\hline \multirow{2}{*}{\multicolumn{4}{|c|}{$\begin{array}{l}\text { Compared to seagrass } \\
\left(\mathrm{Q}_{\mathrm{b}}=148.27 ; \mathrm{p}=0.001 ; \mathrm{df}=4,370\right)\end{array}$}} & Macroalgae & 7 & -0.406 & -1.390 to +0.393 \\
\hline & & & & Open water & 34 & +0.071 & -0.273 to +0.283 \\
\hline Subtidal creeks & 38 & -0.431 & -0.902 to -0.165 & Seagrass & 78 & -1.009 & -1.245 to -0.714 \\
\hline Vegetated edge & 175 & -0.488 & -0.703 to -0.205 & Oyster reef & 6 & +1.298 & +0.243 to +2.241 \\
\hline Nonvegetated edge & 150 & -0.610 & -0.847 to -0.442 & \multirow{2}{*}{\multicolumn{4}{|c|}{$\begin{array}{l}\text { Compared to open water } \\
\left(Q_{b}=34.52 ; p=0.001 ; d f=5,87\right)\end{array}$}} \\
\hline Vegetated inner & 4 & -9.489 & -11.824 to -4.509 & & & & \\
\hline \multirow{2}{*}{\multicolumn{4}{|c|}{ Fish }} & $\begin{array}{l}\left(Q_{\mathrm{b}}=34.52 ; \mathrm{p}=0.00\right. \\
\text { Subtidal creeks }\end{array}$ & 8 & +0.145 & -0.606 to +0.548 \\
\hline & & & & Vegetated edge & 40 & +0.976 & +0.720 to +1.225 \\
\hline \multirow{2}{*}{\multicolumn{4}{|c|}{$\begin{array}{l}\text { Compared to all marsh types (VE, VI, NVE, PP, ITC, STC) } \\
\left(\mathrm{Q}_{\mathrm{b}}=12.84 ; \mathrm{p}=0.049 ; \mathrm{df}=3,338\right)\end{array}$}} & Nonvegetated edge & 4 & -0.505 & -1.901 to +0.128 \\
\hline & & & & Intertidal creeks & 12 & +0.055 & -0.473 to +0.341 \\
\hline Macroalgae & 25 & -0.195 & -0.780 to +0.165 & Vegetated inner & 14 & -0.194 & -0.679 to +0.371 \\
\hline Open water & 99 & -0.039 & -0.317 to +0.301 & Pools and ponds & 10 & +0.243 & -0.347 to +0.644 \\
\hline Seagrass & 207 & -0.474 & -0.673 to -0.295 & \multirow{2}{*}{\multicolumn{4}{|c|}{$\begin{array}{l}\text { Compared to seagrass } \\
\left(\mathrm{Q}_{\mathrm{b}}=82.11 ; \mathrm{p}=0.002 ; \mathrm{df}=4,164\right)\end{array}$}} \\
\hline Oyster reef & 8 & +0.957 & -0.231 to +2.449 & & & & \\
\hline \multicolumn{4}{|c|}{$\begin{array}{l}\text { Compared to all nonvegetated marsh (NVE, PP, ITC, STC) } \\
\left(\mathrm{Q}_{\mathrm{b}}=2.71 ; \mathrm{p}=0.204 ; \mathrm{df}=3,187\right)\end{array}$} & Subtidal creeks & 12 & -0.721 & -1.758 to -0.080 \\
\hline Macroalgae & 25 & -0.183 & -0.691 to +0.142 & Vegetated edge & 85 & -0.449 & -0.798 to -0.065 \\
\hline Open water & 45 & +0.050 & -0.312 to +0.462 & Nonvegetated edge & 62 & -1.078 & -1.496 to -0.753 \\
\hline Seagrass & 115 & -0.304 & -0.538 to -0.171 & Vegetated inner & 2 & -10.950 & -25.735 to -10.950 \\
\hline Oyster reef & 3 & -0.217 & -3.296 to +0.498 & Pools and ponds & 4 & -0.418 & -2.897 to -0.301 \\
\hline
\end{tabular}


Table 5. Nekton species included in the density meta-analyses. For the comparisons of vegetated marsh with nonvegetated marsh, a positive effect size $(E)$ indicates significantly $(p<0.05)$ higher densities in vegetated marsh. In other comparisons, a positive E indicates significantly higher density in marsh compared with either open water or seagrass. At least 2 comparisons were needed to record an effect size; ns = nonsignificant. Brevoortia tyrannus is not included under fishes because of too few comparisons

\begin{tabular}{|c|c|c|c|c|c|c|c|c|c|c|}
\hline \multirow[t]{3}{*}{ Species } & \multirow{2}{*}{\multicolumn{2}{|c|}{$\begin{array}{l}\text { Vegetated marsh vs } \\
\text { Nonvegetated marsh }\end{array}$}} & \multicolumn{4}{|c|}{ Vegetated marsh vs } & \multicolumn{4}{|c|}{ Nonvegetated marsh vs } \\
\hline & & & \multicolumn{2}{|c|}{ Open water } & \multicolumn{2}{|c|}{ Seagrass } & \multicolumn{2}{|c|}{ Open water } & \multicolumn{2}{|c|}{ Seagrass } \\
\hline & $\mathrm{E}$ & $\mathrm{N}$ & $\mathrm{E}$ & $\mathrm{N}$ & $\mathrm{E}$ & $\mathrm{N}$ & $\mathrm{E}$ & $\mathrm{N}$ & $\mathrm{E}$ & $\mathrm{N}$ \\
\hline Fishes & ns & 322 & ns & 54 & -0.3937 & 92 & ns & 45 & -0.29 & 115 \\
\hline Acanthopagrus australis & & 1 & & & & & & & & \\
\hline Anguilla rostrata & & & & & & & & 1 & & 1 \\
\hline Archosargus probatocephalus & & & & 1 & & 1 & & & & \\
\hline Arius felis & ns & 7 & & & & & & & & \\
\hline Arrhamphus sclerolepis & & 1 & & & & & & & & \\
\hline Bairdiella chrysoura & +0.39 & 14 & +0.44 & 3 & $\mathrm{~ns}$ & 4 & & & ns & 5 \\
\hline Brevoortia patronus & -0.52 & 30 & $\mathrm{~ns}$ & 5 & $\mathrm{~ns}$ & 4 & $\mathrm{~ns}$ & 6 & $\mathrm{~ns}$ & 5 \\
\hline Citharichthys spilopterus & -0.25 & 9 & & & $\mathrm{~ns}$ & 3 & & & ns & 4 \\
\hline Cynoscion arenarius & & & -0.28 & 2 & & & & & & \\
\hline Cynoscion nebulosus & +0.18 & 30 & +0.88 & 3 & -0.41 & 13 & & & -0.50 & 13 \\
\hline Elops saurus & $\mathrm{ns}$ & 4 & & & & & & & & \\
\hline Eucinostomus argenteus & -0.31 & 4 & & & & & & & & \\
\hline Gerres subfasciatus & & 1 & & & & & & & & \\
\hline Lagodon rhomboides & +0.62 & 39 & ns & 4 & $\mathrm{~ns}$ & 17 & & 1 & -0.98 & 12 \\
\hline Leiostomus xanthurus & -0.51 & 32 & -1.10 & 6 & $\mathrm{~ns}$ & 10 & +1.12 & 2 & $\mathrm{~ns}$ & 14 \\
\hline Micropogonias undulatus & -0.49 & 19 & -1.45 & 2 & -1.19 & 2 & -0.36 & 3 & $\mathrm{~ns}$ & 4 \\
\hline Mugil cephalus & +0.18 & 40 & +0.62 & 9 & ns & 10 & ns & 3 & $\mathrm{~ns}$ & 9 \\
\hline Mugil curema & +0.45 & 2 & & & & & & & & \\
\hline Myrophis punctatus & -0.16 & 26 & & & -0.4186 & 15 & & & -0.5147 & 14 \\
\hline Opsanus beta & ns & 3 & & & & & & & & \\
\hline Orthopristis chrysoptera & ns & 4 & & & & & & & & \\
\hline Paralichthys dentatus & & & & & & & & & & 1 \\
\hline Paralichthys lethostigma & $\mathrm{ns}$ & 13 & & & & & & & & \\
\hline Pseudopleuronectes americanus & & & & & & & -0.30 & 18 & -0.29 & 19 \\
\hline Sciaenops ocellatus & ns & 6 & ns & 6 & & 1 & +3.05 & 3 & & 1 \\
\hline Sillago maculata & & 1 & & & & & & & & \\
\hline Symphurus plagiusa & -0.32 & 36 & -1.09 & 13 & -2.1472 & 12 & -0.71 & 8 & ns & 11 \\
\hline Tautoga onitis & & & & & & & & & -0.62 & 2 \\
\hline Decapod crustaceans & +0.82 & 221 & +0.68 & 54 & -0.34 & 87 & ns & 34 & -0.91 & 78 \\
\hline Callinectes sapidus & +1.17 & 75 & +0.57 & 24 & -0.54 & 40 & $\mathrm{~ns}$ & 18 & -1.12 & 37 \\
\hline Callinectes similis & & 1 & & & & & & 1 & & 1 \\
\hline Crangon crangon & & & & & & & & 2 & & \\
\hline Farfantepenaeus aztecus & +0.84 & 71 & +0.59 & 15 & ns & 20 & ns & 8 & -0.97 & 18 \\
\hline Farfantepenaeus duorarum & +0.87 & 19 & +0.59 & 4 & -0.42 & 11 & & & -1.19 & 10 \\
\hline Litopenaeus setiferus & +0.38 & 51 & +1.07 & 11 & ns & 13 & -0.82 & 5 & $\mathrm{~ns}$ & 11 \\
\hline Macrobrachium ohione & +0.82 & 4 & & & $\mathrm{~ns}$ & 3 & & & & 1 \\
\hline
\end{tabular}

For overall nekton, we examined the relationships between latitude, tidal range and effect size. For comparisons of densities in salt marsh (all marsh components combined) versus open water, there was a significant negative relationship between tidal range and effect size (slope $=-0.66$, df $=1,186, \mathrm{p}=0.001$ ), indicating that selection for salt marsh over open water declined as tidal range increased (Fig. 1). A significant relationship was also present between latitude and effect size, but the slope was much closer to 0 (slope = -0.018 , df $=1,186, p=0.038$ ). For comparisons of densities in salt marsh (all marsh components) versus seagrass, there was also a significant negative relation- ship between tidal range and effect size (slope $=-0.39$, $\mathrm{df}=1,371, \mathrm{p}=0.009$ ), indicating that selection for seagrass over salt marsh was less intense at lower tidal ranges. There was no significant effect of latitude on selection for seagrass over salt marsh $(\mathrm{df}=1,371, \mathrm{p}=$ $0.187)$.

\section{Growth}

The 5 studies that met our criteria and provided growth rates in salt marshes varied in the species examined and in experimental approach (Table 7). The 
Table 6. Meta-analysis comparisons of nekton densities in different coastal areas, salinity regimes and seasons. For the comparisons of vegetated marsh with nonvegetated marsh, a positive effect size $(E)$ indicates significantly $(p<0.05)$ higher densities in vegetated marsh. In other comparisons, a positive E indicates significantly higher density in marsh compared with either open water or seagrass. At least 2 comparisons were needed to record an effect size; ns $=$ nonsignificant. Results in bold print indicate that the $\mathrm{Q}_{\mathrm{b}}$ (between treatments, e.g. coastal areas) was significant $(\mathrm{p}<0.05)$, and the effect sizes were different for that comparison

\begin{tabular}{|c|c|c|c|c|c|c|c|c|c|c|}
\hline \multirow{3}{*}{ Comparison } & \multirow{2}{*}{\multicolumn{2}{|c|}{$\begin{array}{l}\text { Vegetated marsh vs } \\
\text { Nonvegetated marsh }\end{array}$}} & \multicolumn{4}{|c|}{ Vegetated marsh vs } & \multicolumn{4}{|c|}{ Nonvegetated marsh vs } \\
\hline & & & \multicolumn{2}{|c|}{ Open water } & \multicolumn{2}{|c|}{ Seagrass } & \multicolumn{2}{|c|}{ Open water } & \multicolumn{2}{|c|}{ Seagrass } \\
\hline & $\mathrm{E}$ & $\mathrm{N}$ & $\mathrm{E}$ & $\mathrm{N}$ & $\mathrm{E}$ & $\mathrm{N}$ & E & $\mathrm{N}$ & $\mathrm{E}$ & $\mathrm{N}$ \\
\hline Fishes & ns & 322 & ns & 54 & -0.3937 & 92 & ns & 45 & -0.29 & 115 \\
\hline \multicolumn{11}{|l|}{ Coastal area } \\
\hline US Atlantic & & & -1.71 & 8 & -2.60 & 5 & -0.38 & 21 & -0.33 & 27 \\
\hline US Gulf of Mexico & ns & 317 & ns & 46 & -0.28 & 87 & ns & 24 & -0.27 & 87 \\
\hline \multicolumn{11}{|l|}{ Salinity regime } \\
\hline Oligohaline & ns & 59 & +0.54 & 3 & $\mathrm{~ns}$ & 16 & +0.80 & 2 & ns & 17 \\
\hline Mesohaline & ns & 91 & ns & 14 & -0.76 & 14 & ns & 8 & -0.67 & 13 \\
\hline Polyhaline & ns & 172 & ns & 37 & -0.41 & 62 & ns & 35 & -0.33 & 85 \\
\hline \multicolumn{11}{|l|}{ Season } \\
\hline Spring & ns & 163 & ns & 23 & -0.33 & 40 & ns & 18 & -0.2 & 48 \\
\hline Summer & ns & 59 & -1.18 & 4 & ns & 15 & -0.54 & 7 & ns & 15 \\
\hline Fall & ns & 84 & ns & 27 & -0.43 & 37 & ns & 14 & -0.37 & 42 \\
\hline Winter & ns & 11 & & & & & & & & \\
\hline Decapod crustaceans & +0.82 & 221 & +0.68 & 54 & -0.34 & 87 & ns & 34 & -0.91 & 78 \\
\hline \multicolumn{11}{|l|}{ Coastal area } \\
\hline US Atlantic & -0.63 & 2 & ns & 4 & -6.37 & 4 & ns & 10 & -1.07 & 14 \\
\hline US Gulf of Mexico & +0.83 & 219 & +0.80 & 50 & -0.23 & 83 & ns & 22 & -0.88 & 64 \\
\hline \multicolumn{11}{|l|}{ Salinity regime } \\
\hline Oligohaline & +0.57 & 35 & +1.04 & 4 & ns & 17 & & & -0.68 & 15 \\
\hline Mesohaline & +0.56 & 64 & +0.55 & 17 & -0.49 & 20 & $\mathrm{~ns}$ & 12 & -0.96 & 16 \\
\hline Polyhaline & +1.04 & 117 & +0.73 & 33 & -0.36 & 50 & ns & 22 & -0.99 & 47 \\
\hline \multicolumn{11}{|l|}{ Season } \\
\hline Spring & +0.81 & 81 & +0.66 & 16 & ns & 25 & ns & 12 & -0.65 & 23 \\
\hline Summer & +1.10 & 31 & $\mathrm{~ns}$ & 4 & $\mathrm{~ns}$ & 12 & ns & 3 & -1.33 & 8 \\
\hline Fall & +0.81 & 98 & +0.86 & 30 & -0.59 & 42 & ns & 15 & -0.88 & 41 \\
\hline Winter & ns & 6 & & & & & & & & \\
\hline
\end{tabular}

most extensive study was conducted by Phelan et al. (2000) in estuaries of Connecticut and New Jersey. They measured growth of caged young-of-the-year tautog Tautoga onitis and winter flounder Pseudopleuronectes americanus in subtidal marsh creeks, seagrass, open water and macroalgae beds. Irlandi \& Crawford (1997) compared growth of pinfish Lagodon rhomboides in enclosures between vegetated marsh edge with seagrass and vegetated marsh edge without seagrass in North River, North Carolina. We considered this study to be a comparison of vegetated marsh edge and seagrass, but it could also be considered a comparison of nonvegetated marsh edge and seagrass. On the US Gulf of Mexico Coast, Zimmerman \& Minello (1984a) and Minello \& Zimmerman (1991) reported results on caged brown shrimp Farfantepenaeus aztecus and white shrimp Litopenaeus setiferus in areas with and without access to marsh edge, and Stunz et al. (2002a) used solid walled field mesocosms to compare growth of juvenile red drum Sciaenops ocellatus in salt marsh (vegetated edge and nonvege- tated edge), seagrass and oyster reef. Using a different approach, Whaley (1997) brought cores of marsh sediment into the laboratory to measure growth of brown shrimp and white shrimp in association with different marsh types. We entered growth into our database as $\mathrm{mm} \mathrm{d}^{-1}$ except for values reported for pinfish by Irlandi \& Crawford (1997) that were entered as a change in weight ( $g$ ) over the $45 \mathrm{~d}$ experimental period.

Most growth comparisons between marshes and other habitat types were based on fish in subtidal marsh creeks (Phelan et al. 2000) or nonvegetated marsh edge (Stunz et al. 2002a). A meta-analysis of these comparisons indicated that growth in nonvegetated marsh was not significantly different from growth in open water or in macroalgae beds, but was significantly lower than growth in seagrass $(\mathrm{E}=$ -1.253). Nekton growth (mainly penaeid shrimp) in vegetated marsh edge and nonvegetated marsh edge has been measured in Texas using 3 different approaches (Zimmerman \& Minello 1984a, Whaley 1997, Stunz et al. 2002a). Although results appeared to 


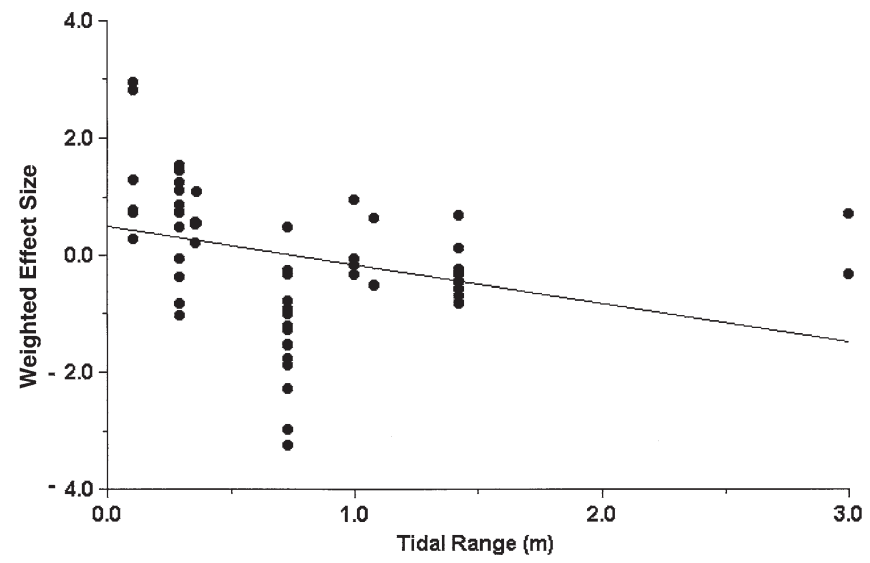

Fig. 1. Relationship between tidal range and nekton selection (based on density) for salt marsh over open water. Larger effect sizes indicate a stronger selection for marsh

vary with species (Table 7), a meta-analysis of 7 comparisons indicated that overall growth was significantly higher in vegetated marsh compared with nonvegetated marsh $(E=+0.58)$. We found only 2 studies where growth was compared between vegetated salt marsh and non-marsh habitat types. Irlandi \& Crawford (1997) reported negative growth (measured as biomass) of Lagodon rhomboides in vegetated marsh (with nonvegetated marsh) compared with positive growth in seagrass (and vegetated marsh). Stunz et al. (2002a), found no significant difference in growth of young Sciaenops ocellatus between vegetated marsh edge and seagrass, while growth rates in these vegetated habitat types were significantly higher than in nonvegetated marsh edge and oyster reefs.

\section{Survival}

We identified 11 studies that compared nekton survival in salt marshes with other habitat types (Table 8). Mortality in all of these studies was attributed to predation, although other sources could have been important in tethering studies. Five of the studies were field tethering experiments using either young blue crabs (4 studies) or brown shrimp as the prey. Survival in subtidal marsh creeks was compared with open water and seagrass in Chesapeake Bay and New Jersey (Shirley et al. 1990, Wilson et al. 1990a, Ryer et al. 1997). Survival within marsh edge vegetation was compared with open water and seagrass in Mobile Bay and Mississippi Sound, AL (Heck et al. 1994) and Christmas Bay, TX (Minello 1993). In laboratory studies, prey consisted of juvenile decapod crustaceans (American lobster Homarus americanus, Farfantepenaeus aztecus, Litopenaeus setiferus, Callinectes sapidus) and 1 species of fish (Sciaenops ocellatus). Predators consisted mainly of fishes although crabs were occasionally used (Table 8). Marsh treatments consisted of marsh peat reefs, planted Spartina alterniflora, or green straws that simulated the structure of emergent marsh vegetation. The data from all studies were converted to percent survival in each habitat type.

Our meta-analysis of the entire data set indicated that survival in salt marsh was significantly higher than survival in open water, significantly lower than in oyster reef/cobble and not significantly different from seagrass (Table 9). Results from field tethering studies were similar. If we limited the analysis to laboratory studies, the same patterns were apparent, but survival attributed to salt marsh vegetative structure was lower than survival in seagrass.

\section{DISCUSSION}

\section{Density patterns}

Nekton densities should be one indicator of habitat value and by far, most of the data available to assess the nursery value of salt marshes is on density. Our metaanalyses of density patterns allowed us to generally rank habitat types. For all nekton (fishes and decapod crustaceans), densities in salt marshes appeared similar to densities in open water and macroalgae beds. These densities, however, were lower than those in seagrass and higher than those in oyster reefs. Vegetated marsh edge generally had higher densities than other marsh types and overall rankings appeared to be: seagrass $>$ vegetated marsh edge > nonvegetated marsh, open water, macroalgae $>$ vegetated inner marsh $>$ oyster reef. For fishes alone, this ranking differed slightly: seagrass > vegetated marsh edge, nonvegetated marsh, open water, macroalgae, oyster reefs > vegetated inner marsh. We graphically represented these density relationships among some different habitat types by calculating effect sizes in comparison with vegetated marsh edge and modifying results to eliminate negative values (Fig. 2). Fishes in our analysis were represented by 29 species and patterns of habitat use varied among species. However, the relative value of salt marsh and seagrass beds was consistent; densities were higher in seagrass for all fish species where a significant difference occurred between these habitat types. Density patterns for decapod crustaceans indicated a ranking of: seagrass > vegetated marsh edge > nonvegetated marsh, vegetated inner marsh, open water, macroalgae > oyster reef (Fig. 2). Although 7 species of crustaceans were included in the analysis, most comparisons were for blue crabs, brown shrimp and white shrimp. Densities of the 2 shrimp species were not significantly differ- 


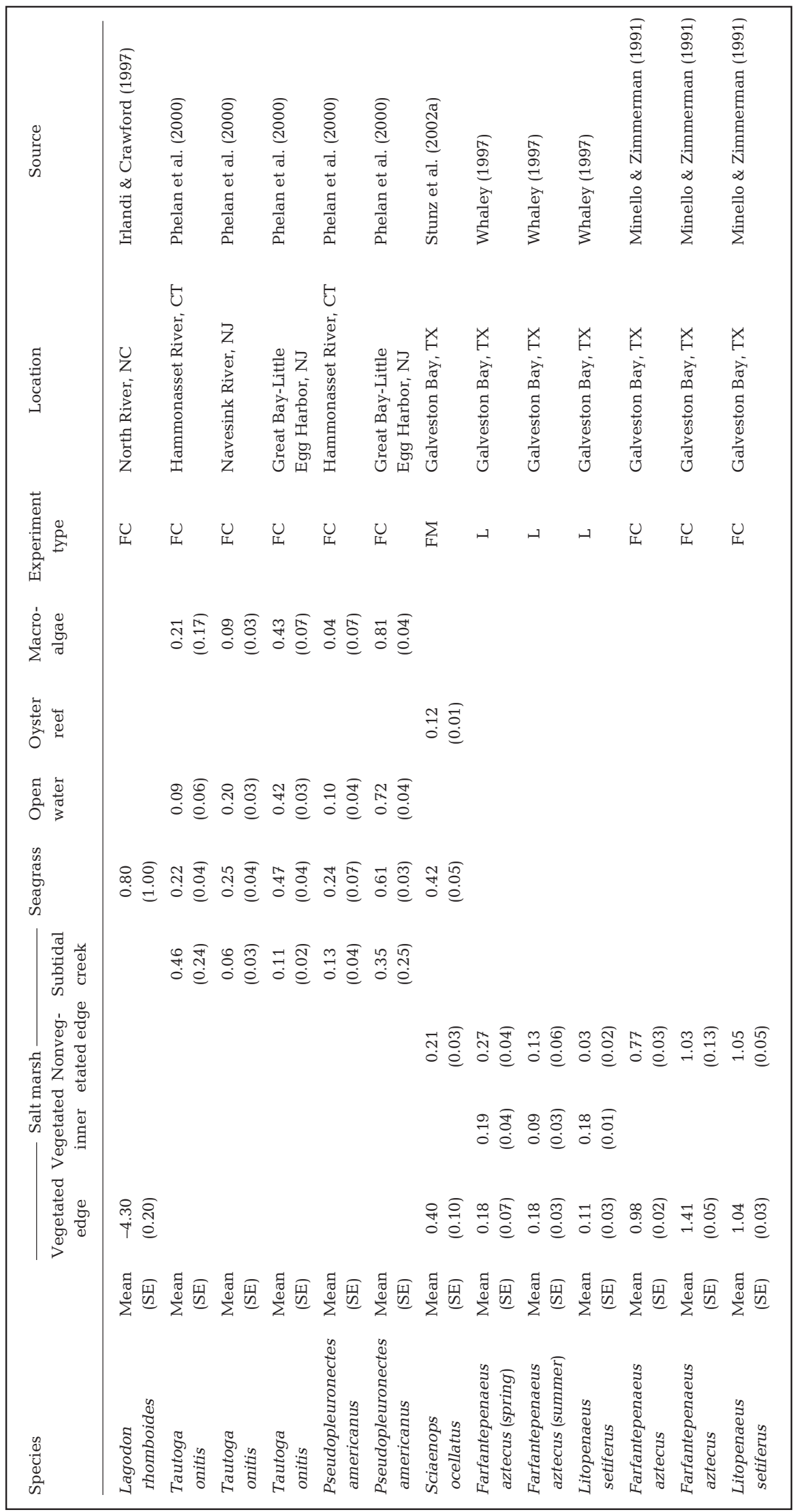




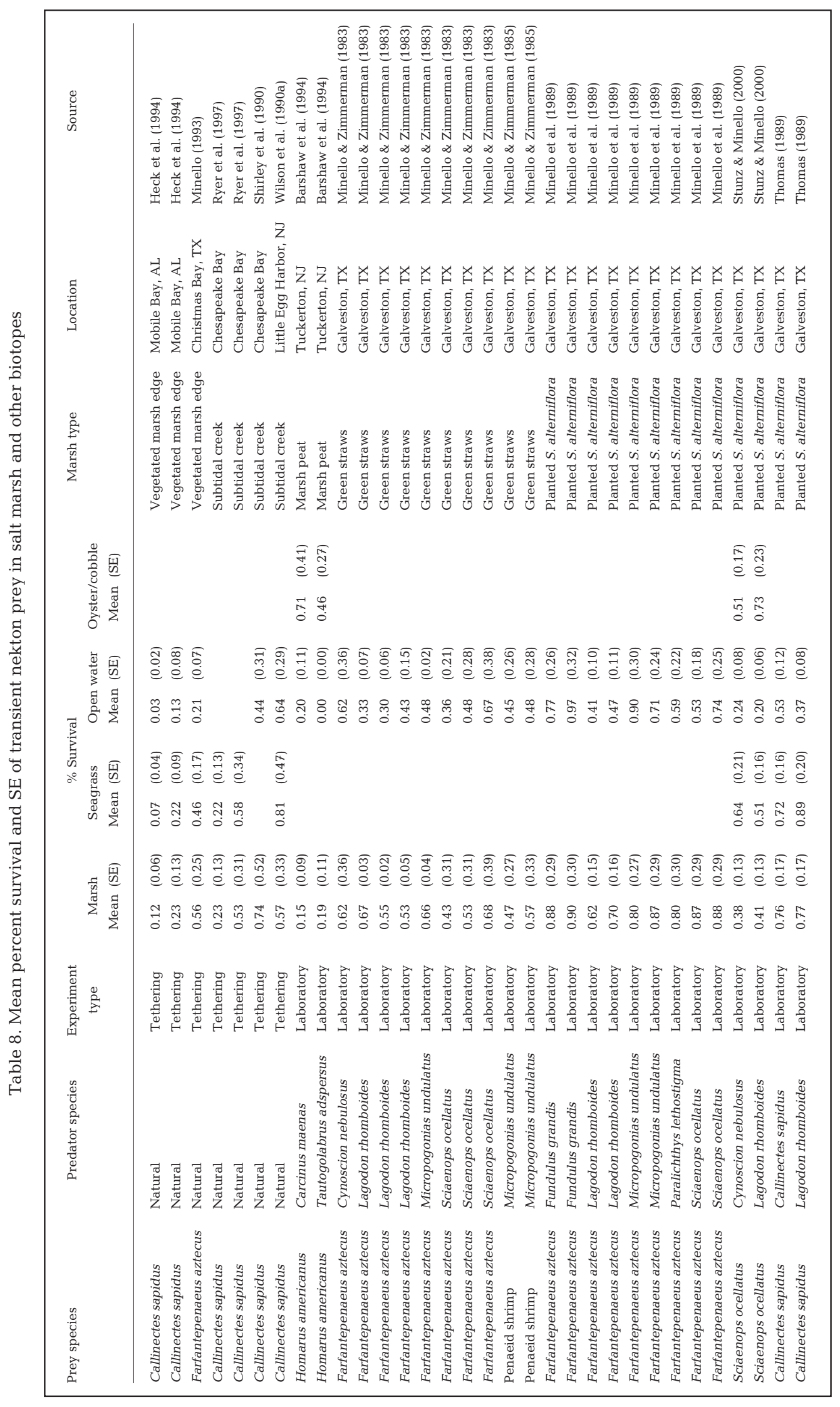


Table 9. Results of meta-analysis comparing nekton survival between salt marsh and other biotopes. A significant Q-value between biotopes $\left(Q_{b}\right)$ indicates that the effect size $(E)$ differs among the biotopes in that comparison. The effect size is based on Hedges' $d$, and a positive value indicates relatively high survival in the experimental habitat type (marsh) compared with the control habitat type (other biotopes). An effect is considered significant if the $95 \%$ confidence interval does not overlap 0

\begin{tabular}{|c|c|c|c|}
\hline Biotope & $\begin{array}{r}\text { No. o } \\
\text { comparis }\end{array}$ & E & $95 \% \mathrm{CI}$ \\
\hline \multicolumn{4}{|c|}{$\begin{array}{l}\text { All data included } \\
\left(\mathrm{Q}_{\mathrm{b}}=28.73 ; \mathrm{p}=0.001 ; \mathrm{df}=2,43\right)\end{array}$} \\
\hline Open water & 30 & +0.64 & +0.440 to +0.885 \\
\hline Oyster/cobble & 4 & -1.005 & -2.204 to -0.608 \\
\hline Seagrass & 10 & -0.28 & -0.657 to +0.029 \\
\hline \multicolumn{4}{|c|}{$\begin{array}{l}\text { Only comparisons with structured marsh } \\
\left(\mathrm{Q}_{\mathrm{b}}=27.52 ; \mathrm{p}=0.001 ; \mathrm{df}=2,38\right)\end{array}$} \\
\hline Open water & 28 & +0.651 & +0.432 to +0.885 \\
\hline Oyster/cobble & 4 & -0.996 & -2.990 to -0.608 \\
\hline Seagrass & 7 & -0.223 & -0.588 to +0.138 \\
\hline \multicolumn{4}{|c|}{$\begin{array}{l}\text { Only comparisons with subtidal marsh creeks } \\
\left(\mathrm{Q}_{\mathrm{b}}=0.98 ; \mathrm{p}=0.480 ; \mathrm{df}=1,4\right)\end{array}$} \\
\hline Open water & 2 & +0.543 & -0.530 to +2.427 \\
\hline Seagrass & 3 & -0.712 & -1.401 to +0.013 \\
\hline \multicolumn{4}{|c|}{$\begin{array}{l}\text { Only laboratory comparisons } \\
\left(\mathrm{Q}_{\mathrm{b}}=25.65 ; \mathrm{p}=0.001 ; \mathrm{df}=2,32\right)\end{array}$} \\
\hline Open water & 25 & +0.622 & +0.406 to +0.890 \\
\hline Oyster/cobble & 4 & -1.014 & -2.211 to -0.608 \\
\hline Seagrass & 4 & -0.401 & -0.894 to -0.034 \\
\hline \multicolumn{4}{|c|}{$\begin{array}{l}\text { Only field tethering comparisons } \\
\left(\mathrm{Q}_{\mathrm{b}}=2.93 ; \mathrm{p}=0.083 ; \mathrm{df}=1,10\right)\end{array}$} \\
\hline Open water & 5 & +0.808 & +0.031 to +1.632 \\
\hline Seagrass & 6 & -0.068 & -0.878 to +0.238 \\
\hline
\end{tabular}

ent between seagrass and vegetated marsh edge. Our meta-analysis of nekton density patterns indicates that species selectively use different components of salt marshes and therefore, comparisons of salt marshes with other habitat types are strongly affected by the marsh components examined. Because salt marshes are intertidal, there is also a temporal complexity inherent in density comparisons. Information on tidal stage at the time of collection was not always available, but most comparisons were made at high tide when marsh vegetation was flooded. During low tide, densities in nonvegetated marsh will be elevated for most nekton and comparisons among habitat types may differ (Cicchetti \& Diaz 2000).

There are many variables that can affect nekton density patterns in estuaries (Craig \& Crowder 2000) and that may interact with utilization of different biotopes. Our meta-analyses indicated that habitat use was affected by salinity regime, tidal range, season and geographic location. Salinity patterns in estuaries often have been shown to coincide with dramatic shifts in the distribution and abundance of young nekton (Weinstein et al. 1980b, Zimmerman et al. 1990a,b, Baltz et al. 1993, Bulger et al. 1993, Whitfield 1994). The location of salt marshes in the estuarine landscape is also important, and proximity to barrier islands (Weinstein et al. 1980b) and seagrass beds (Rozas \& Odum 1987, Irlandi \& Crawford 1997) appears to affect marsh use.

Certain data limitations need to be considered in assessing the value of our meta-analyses on nekton densities. The data used in these comparisons are highly biased towards the Atlantic and Gulf of Mexico coasts of the US. However, salt marsh systems are distributed throughout the world (Chapman 1960); and young transient nekton have been collected in salt marshes on the western coast of the US (Shreffler et al. 1990, Chamberlain \& Barnhart 1993, Desmond et al. 2000), in Europe (Drake \& Arias 1991, Cattrijsse et al. 1994, Costa et al. 1994, Laffaille et al. 1998, Mathieson et al. 2000), Africa (Whitfield 1994, Paterson \& Whitfield 1996) and Australia (Connolly 1999). The prepon-
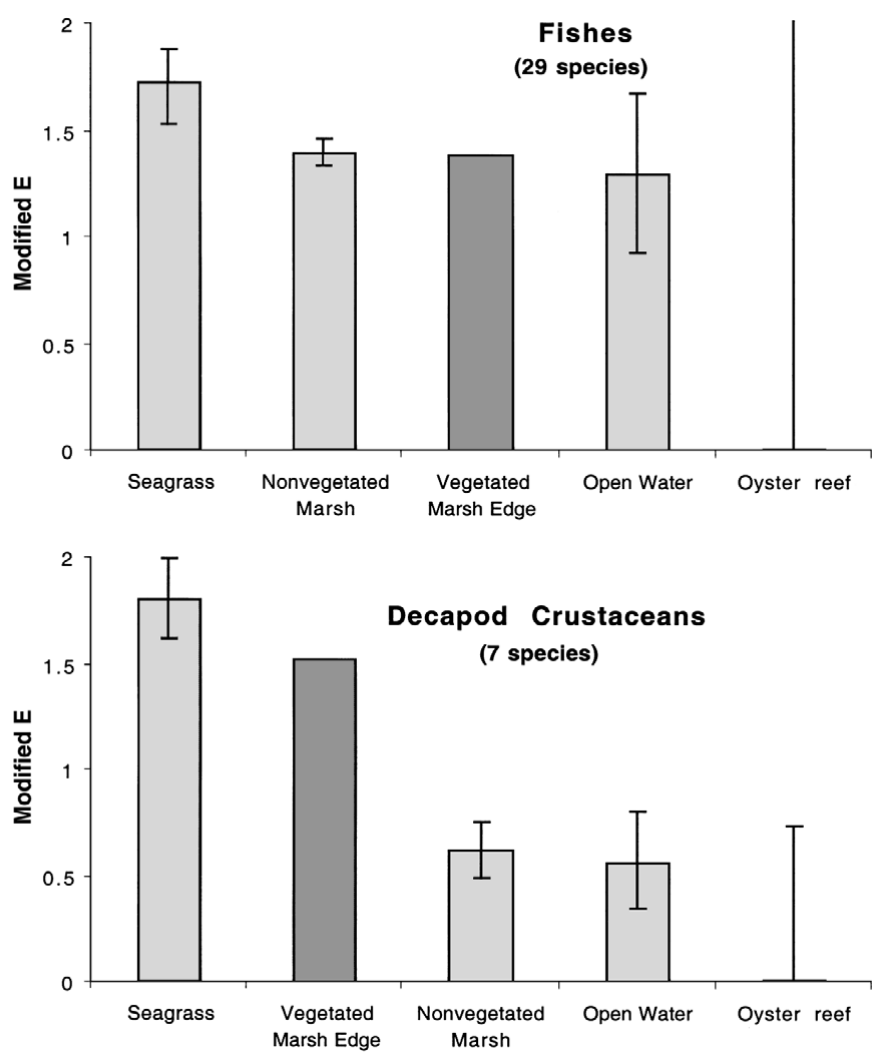

Fig. 2. Density relationships among habitat types based on meta-analysis effect sizes. All habitat types are compared with vegetated marsh edge. The absolute value of the lowest effect size (oyster reef) was added to each effect size to convert all values to positive numbers. Error bars are $95 \%$ confidence intervals and can be used to compare habitat types with vegetated marsh edge 
derance of studies in our analyses from the northern Gulf of Mexico should be noted because extended tidal flooding in these salt marshes may increase use of the marsh surface (Rozas 1993, 1995, Zimmerman et al. 2000) and density patterns in the Gulf may not be similar to patterns in other coastal regions of the world. We could not directly address hypotheses regarding flooding duration and nekton use of the marsh surface, because these data have been infrequently measured outside the northern Gulf of Mexico where tidal range is low and flooding duration is often high (Rozas \& Reed 1993, Rozas 1995). However, nekton use of salt marshes in relation to open water appeared to be greater in the Gulf of Mexico than along the Atlantic coast of the US (Table 6) and was negatively related to tidal range (Fig. 1). Density comparisons may also be affected by errors in our assignment of data to habitat types and by the spatial scale of our habitat classification. For example, we assigned nekton densities to nonvegetated marsh edge if they were obtained on nonvegetated bottom within approximately $10 \mathrm{~m}$ of marsh vegetation. There is some evidence, however, that within this marsh type, some fishes selectively use a much narrower band just outside of the vegetation (Baltz et al. 1993, Stunz et al. 2002b). In addition, comparisons from our data are limited by the relative lack of information on nekton densities in water deeper than about $1 \mathrm{~m}$ due to gear restrictions (Rozas \& Minello 1997, Connolly 1999).

\section{Growth and survival}

The nursery function of a habitat is related to the export of secondary production (Beck et al. 2001). Thus, growth and survival within habitats are important characteristics defining nursery value for nekton. The measurement of these variables, however, has been problematic, especially with regard to specific habitat types.

Relatively few studies have examined growth rates of transient nekton species in salt marshes. The comparisons we found were mainly restricted to measurements of fish growth in subtidal marsh creeks and penaeid shrimp growth in vegetated and nonvegetated marsh edge. Fish growth in subtidal marsh creeks was similar to growth in open water and macroalgae beds, but lower than in seagrass. Most of these data were from an extensive field caging study by Phelan et al. (2000) in New Jersey and Connecticut, and they concluded that growth rates varied with fish species, habitat type, estuary and year. Low growth rates of Pseudopleuronectes americanus in marsh creeks were attributed to low dissolved oxygen levels $\left(<2 \mathrm{mg} \mathrm{l}^{-1}\right)$. Experimental data on growth of penaeid shrimps in salt marshes suggest that while overall growth rates appear higher in vegetated marsh edge compared with nonvegetated marsh edge, results vary with shrimp species and experimental techniques. Growth rates reported by Zimmerman \& Minello (1984a) and Minello \& Zimmerman (1991) appear to approach natural shrimp growth rates (Knudsen et al. 1977), and they found that Farfantepenaeus aztecus grew better in vegetated marsh but Litopenaeus setiferus did not. Whaley (1997) brought cores of marsh sediment into the laboratory and obtained different results for the same 2 shrimp species. Overall growth in her experiments was relatively low, and food limitation may have occurred (Whaley 1997). In a study on juvenile Sciaenops ocellatus growth, Stunz et al. (2002a) found no significant differences between vegetated marsh edge and seagrass, while growth rates in these vegetated habitat types were significantly higher than in nonvegetated marsh edge (sand bottom) or on oyster reefs. Overall, these data indicate that the type of marsh included in a study affects comparisons of nekton growth: growth in nonvegetated marsh may be similar to open water, oyster reef and macroalgae beds, while growth in vegetated marsh can be similar to growth in seagrass beds. However, the limited availability of data makes these conclusions highly speculative. Additionally, there is evidence for species-specific differences in growth patterns.

No single technique appears to adequately address experimental difficulties and artifacts encountered in the measurement of habitat-specific growth rates of nekton (Peterson \& Black 1994, Underwood 1997). In salt marshes, experimental problems are exacerbated by tidal dynamics. Enclosures or cages have been used to limit nekton movement and relate growth to a particular habitat type, but this restriction is unnatural for highly mobile organisms and may affect results. As an example, apparent low growth rates in marsh creeks observed by Phelan et al. (2000) may have been caused by forcing fish in cages to endure periodic low dissolved oxygen conditions in creeks; under free ranging conditions, fish may have escaped effects of hypoxia. Similarly, caging nekton on the marsh surface prevents normal access to low tide refuges. In addition, if growth is food limited, the size of enclosures, wall construction, type of food required and density of experimental animals can interact with results. Growth of shrimp in marsh cores measured by Whaley (1997) was apparently food limited, and this limitation may have prevented the detection of some differences among her treatments. The interpretation of habitat-specific growth rates is also made difficult by extensive variation between years and estuaries such as that observed by Phelan et al. (2000). In summary, while habitatspecific growth should be an important measure of 
nursery value (Beck et al. 2001), there are insufficient data available to use growth rates for effectively comparing marshes with other habitat types. In the future, mark-recapture and remote sensing studies on tagged and free-ranging juvenile nekton should improve our ability to measure habitat-related growth by allowing us to relate growth to home range and site fidelity. Recent growth rates of captured nekton can be assessed through measurements of otolith microstructure (Baltz et al. 1998, Rooker et al. 1999), accumulation rates of cellular pigments (Vila et al. 2000) and metabolic processes (Rooker et al. 1997, Buckley et al. 1999, Westerman et al. 1999); however, problems determining where nekton have been before capture restrict the utility of these techniques for measuring habitatspecific growth (Stunz et al. 2002a).

Habitat-specific estimates of survival may be one of the most useful ways to measure habitat quality for nekton and thus, help to identify nursery habitats. In our meta-analysis, nekton survival in salt marshes was significantly higher than survival in open water, significantly lower than in oyster reef/cobble and not significantly different from seagrass (Table 9). Similar to growth measurements, comparisons of survival in salt marshes with other habitat types are limited by experimental restrictions; only 2 approaches were used to estimate survival, laboratory predation experiments on the effects of vegetative structure and field tethering experiments. In laboratory experiments, survival was best in structured habitats, but salt marsh structure did not appear to offer as much protection as seagrass and oyster reef/cobble. However, structural complexity of habitats is difficult to reproduce in the laboratory and difficult to quantify (Nelson \& Bonsdorff 1990, Bartholomew et al. 2000). Although controlled laboratory experiments can eliminate confounding variables, results of these studies may not reflect actual survival rates in habitats where environmental conditions and predator abundances may co-vary with habitat types. Tethering experiments have been used to take this natural variability into account, and these experiments indicate that survival in salt marsh and seagrass is better than in open water (Table 9). However, survival of tethered prey may not always reflect survival of untethered prey (Peterson \& Black 1994, Aronson \& Heck 1995, Micheli 1996, Kneib \& Scheele 2000), and tethering generally has been limited to invertebrates because of concerns regarding abnormal behavior of tethered fishes (Minello 1993, Curran \& Able 1998). Advances in the miniaturization of sonic tags and the development of other means of tracking individual organisms may provide techniques to examine both growth and mortality in specific habitat types.

Production of adult nekton that is derived from nursery habitats (as defined by Beck et al. 2001) is difficult to measure, because it depends on density, growth and survival in nurseries. Cicchetti (1998) provides an excellent literature review of salt marsh production estimates for nekton (mainly small resident species) and discusses difficulties in generating these estimates. His production estimate for transient nekton from vegetated salt marsh edge in Chesapeake Bay was $6.6 \mathrm{~g}$ dry wt $\mathrm{m}^{-2} 150 \mathrm{~d}^{-1}$ and was mostly from blue crabs Callinectes sapidus $(6.0 \mathrm{~g})$. He noted that this production of blue crabs was comparable to estimates from a Virginia seagrass bed (Fredette et al. 1990). We found no direct comparisons of transient nekton production between salt marshes and other habitat types in the literature. Estimates of spot Leiostomus xanthurus production have been derived from subtidal marsh creeks in North Carolina (0.05 g dry wt $\mathrm{m}^{-2} \mathrm{mo}^{-1}$ ) by Weinstein \& Walters (1981) and in Virginia (4.6 g dry wt $\mathrm{m}^{-2} 90 \mathrm{~d}^{-1}$ ) by Weinstein et al. (1984). Deegan \& Thompson (1985) estimated production of Atlantic croaker Micropogonias undulatus (23 $\mathrm{g}$ wet $\mathrm{wt} \mathrm{m}^{-2}$ $\mathrm{yr}^{-1}$ ) and gulf menhaden Brevoortia patronus (13 g wet wt $\mathrm{m}^{-2} \mathrm{yr}^{-1}$ ) from estuaries of coastal Louisiana, and they suggested (based on standing crop estimates) that productivity was highest in estuarine systems that were in early stages of marsh disintegration. Herke et al. (1992) estimated production from a 35 ha area of impounded marsh (75\% marsh pond and 25\% Spartina patens vegetation) in Louisiana by assuming that biomass recruiting into the system was negligible and measuring the biomass of emigrating nekton; these annual production estimates were $7.8 \mathrm{~g}$ wet $\mathrm{wt}$ $\mathrm{m}^{-2}$ for C. sapidus, $4.5 \mathrm{~g} \mathrm{~m}^{-2}$ for B. patronus, $3.2 \mathrm{~g} \mathrm{~m}^{-2}$ for $M$. undulatus, $2.4 \mathrm{~g} \mathrm{~m}^{-2}$ for Farfantepenaeus aztecus and $2.2 \mathrm{~g} \mathrm{~m}^{-2}$ for Litopenaeus setiferus. Natural mortality and movement within marsh ecosystems complicates these production measurements, and Deegan (1990) discusses these and additional problems encountered estimating production of estuarine nekton.

The relationships between nekton production and coastal salt marshes can also be examined by looking for large-scale correlative trends. Positive relationships have been observed between the area of coastal wetlands and the landings of commercial shrimp (Turner 1977, 1992, Turner \& Boesch 1988). Our meta-analyses suggest that salt marshes are important nurseries for decapod crustaceans, such as penaeid shrimp and blue crabs, and therefore, we might expect declines in these fishery species to coincide with the loss of coastal wetlands. In this regard, the northern Gulf of Mexico is of interest because of extensive wetland loss $\left(>70 \mathrm{~km}^{2} \mathrm{yr}^{-1}\right.$ over several decades) in the region and because of the abundance of estuarine-dependent fishery species, including decapod crustaceans. However, fishery declines are 
not yet apparent in the northern Gulf, and the complexity of ecological interactions between wetlands and nekton may be affecting such relationships (Boesch \& Turner 1984, Chesney et al. 2000, Zimmerman et al. 2000).

\section{Other considerations}

The ability of nekton to move into and out of biotopes can affect nursery values. The level of successful recruitment bringing larvae and postlarvae into estuaries is an important component of habitat use, controlling initial densities of juveniles in different habitat types. Certain characteristics, such as orientation to shoreline, extent and direction of wind induced currents as well as tidal dynamics, appear to promote successful recruitment into particular estuaries (Weinstein et al. 1980a, Rothlisberg et al. 1983, Weinstein 1988, Rogers et al. 1993, Epifanio 1995, Olmi 1995, Morgan et al. 1996, Wenner et al. 1998). Thus, location with respect to a source of recruits (e.g. tidal passes, inlets) may affect density patterns within habitats and therefore, potential nursery value may never be realized. As an example, Guindon \& Miller (1995) showed that abundance of juvenile southern flounder in marsh creeks was not always related to production potential. The contribution of a biotope to nekton production reaching adult populations is also highly dependent on the successful movement of animals from a potential nursery area to the adult habitat (Beck et al. 2001). Poor survival during this movement, perhaps due to the physical location of the biotope and the distribution of predators, can influence nursery value. This aspect of nurseries is difficult to examine, and we know of no studies on survival of nekton during movement from salt marshes to adult habitats (Gillanders et al. 2003). The importance of movement into and out of nurseries reinforces the necessity to view nursery habitats within the context of the landscape (Simenstad et al. 2000).

Insights into the relative nursery value of habitat types also have been obtained from analyses of diet (Rozas \& LaSalle 1990, Moy \& Levin 1991), bioenergetics (Nixon \& Oviatt 1973, Deegan 1993, Madon et al. 2001), ecophysiological responses (Miller et al. 2000), stable isotopes (Fry \& Sherr 1984, Deegan \& Garritt 1997, Kwak \& Zedler 1997, Wainright et al. 2000, Weinstein et al. 2000), otolith microchemistry (Secor \& Zdanowicz 1998, Campana 1999, Thresher 1999, Gillanders \& Kingsford 2000) and trace elements in body tissues (Courtney et al. 1994). For example, stable isotope analyses have demonstrated that nutrient sources for fishes and crustaceans vary with estuarine location, habitat type, dominant vegetation type and season (Currin et al. 1995, Deegan \& Garritt 1997,
Hughes et al. 2000, Wainright et al. 2000, Weinstein et al. 2000). The assessment of nursery value is an ecosystem problem that will require a basic understanding of trophic relationships and other ecological linkages within and between biotopes. For example, the abundant resident nekton in salt marshes are likely to play an important role in estuarine nursery functions for transient nekton (Kneib \& Wagner 1994, Kneib 1997b, 2000). Ecosystem modeling will be needed to address this complexity.

We found evidence that geographic location (East US coast vs Gulf coast), tidal range and salinity regime affected nekton density patterns and the nursery value of salt marshes. Other landscape level factors may also be important, including the presence or proximity of other habitat types (Weinstein et al. 1980b, Irlandi \& Crawford 1997, Micheli \& Peterson 1999), marsh drainage patterns (Desmond et al. 2000, Simenstad et al. 2000, Webb \& Kneib 2002), connectivity with coastal waters (Herke et al. 1992, Rogers et al. 1994, Rozas \& Minello 1999) and physicochemical gradients (Weinstein et al. 1981, Baltz et al. 1993, Miller et al. 2000). Landscape level salinity patterns also have been shown to affect nekton growth (Baltz et al. 1998) and survival (Weinstein \& Walters 1981); and both salinity and temperature have been associated with productivity of brown shrimp in salt marshes (Ford \& St. Amant 1971).

Salt marshes are really mosaics of different habitat types and hence, we divided marshes into 6 components for analysis. For some nekton, densities varied among all of these marsh types. These distribution patterns, the intertidal nature of salt marshes and the ability of nekton to move among marsh types, suggest that abundance comparisons with other habitat types should really be made at a different spatial scale, rather than on the basis of nekton per $\mathrm{m}^{2}$. Such analyses, however, require the sampling of entire marsh systems or combining small-scale density patterns with landscape pattern analyses. Estimates of average population size in marsh complexes are relatively rare. Havens et al. (1995) sampled an entire marsh system (excluding subtidal creeks) using block nets and calculated overall densities based on the aerial extent of the flooded marsh at mean high tide. This approach will not include nekton that remain on the vegetated marsh surface at low tide, but most of these animals are small resident species (Kneib 1984, 1997a). An alternative approach involves sampling each habitat type within a marsh complex and using a geographic information system to estimate cover of different marsh types and to extrapolate densities to overall marsh populations (Rozas \& Minello 1999, Clark et al. 1999, Minello \& Rozas 2002). 
Appendix 1. Glossary of terms as used in this paper

Biotope. An area or location that is characterized by a recognizable community and is defined by dominant components of structure, plants or physicochemical variables (e.g. coral reefs, seagrass beds, salt marshes, mangroves and oyster reefs)

Density. The number of animals per area of bottom

Enclosure sampler. A sampling device that encloses a known area of bottom and allows the removal of nekton and calculation of density (e.g. drop samplers, throw traps, Wegener rings, lift nets and flume weirs)

Habitat. All places that a population of a species (or life stage of a species) lives

Habitat type. A generic term used to describe any particular place that organisms live

Intertidal creeks. Nonvegetated creeks within a salt marsh complex that drain at low tide

Juvenile habitat. All places that the juveniles of a species occur (see 'Habitat')

Marsh pools and ponds. Nonvegetated open water areas within a salt marsh complex that can range in diameter from $\mathrm{m}$ to several $\mathrm{km}$. These areas are generally surrounded by marsh vegetation (see 'Nonvegetated marsh')

Nekton. Organisms that are free swimming and independent of water currents at some time in their life cycle

Nonvegetated marsh. The areas within a salt marsh complex that are not vegetated with emergent or submerged vascular plants. Areas of submerged aquatic vegetation within the marsh complex were not considered to be marsh in our analyses but considered to be seagrass

Nonvegetated marsh edge. A generic term for areas of nonvegetated bottom (often intertidal) within a salt marsh complex that are within approximately $10 \mathrm{~m}$ of marsh vegetation. There may be overlap between nonvegetated marsh edge and marsh pools and ponds, intertidal and subtidal creeks (see 'Nonvegetated marsh')
Nursery habitat. An area of a juvenile habitat that is especially productive for a species. The contribution per unit area of nursery habitat to the production of individuals that recruit to adult populations is greater, on average, than production from other juvenile habitat areas (Beck et al. 2001)

Open water. A nonvegetated habitat type that is not within a salt marsh complex. These areas within open bays, inlets, coves, bayous, large subtidal channels and coastal lakes are not surrounded by salt marsh vegetation or are large enough (>several $\mathrm{klm}$ in diameter) for the direct influence of marsh vegetation on nekton to be minimal

Salt marsh. A complex of vegetated and nonvegetated habitat types that includes the intertidal vegetated marsh surface, marsh pools and ponds, intertidal and subtidal creeks. Areas of submerged aquatic vegetation and oyster reef can occur within a salt marsh complex, but we considered these areas to be distinct habitat types

Seagrass. Areas populated by submerged vascular plants

Subtidal creeks. Nonvegetated creeks within a salt marsh complex that do not completely drain at low tide

Transient nekton. Nekton species with juvenile and adult habitats that are not completely overlapping

Vegetated inner marsh. The intertidal vegetated surface area of a salt marsh complex that is farther than approximately $5 \mathrm{~m}$ from any nonvegetated bottom. Inner marsh vegetation can be similar to that of the vegetated edge but often includes additional plant species

Vegetated marsh edge. The intertidal vegetated surface area of a salt marsh complex that is within approximately $5 \mathrm{~m}$ from any nonvegetated bottom. In the eastern US, the marsh edge is usually vegetated with Spartina alterniflora, S. patens, Juncus roemerianus, Scirpus spp. or Phragmites australis
Acknowledgements. This study was conducted as part of the Nursery Roles Working Group supported by the National Center for Ecological Analysis and Synthesis, a center funded by the National Science Foundation (grant no. DEB-0072909), University of California and University of California-Santa Barbara. All members of the working group contributed to the design and implementation of our study including $\mathrm{M}$. W. Beck, K. L. Heck Jr., D. L. Childers, D. B. Eggleston, B. M. Gillanders, B. Halpern, K. Hoshino, R. J. Orth, P. F. Sheridan and J. Brown. S. Hagan provided assistance in compiling the databases. L. Rozas, G. Stunz and P. Sheridan provided comments on early drafts of the manuscript.

\section{LITERATURE CITED}

Able KW, Wilson KA, Heck KL (1989) Fishes of vegetated habitats in New Jersey estuaries: composition, distribution, and abundance based on quantitative sampling. Report to the New Jersey Department of Environmental Protection (Grants 4-25662, 4-27521). Rutgers University Center for Coastal and Environmental Studies (CCES) Publication No. 1041, New Brunswick, NJ, p 38

Aronson RB, Heck KL (1995) Tethering experiments and hypothesis testing in ecology. Mar Ecol Prog Ser 121:307-309
Baltz DM (1990) Autecology. In: Schreck CB, Moyle PB (eds) Methods for fish biology. American Fisheries Society, Bethesda, MD, p 585-607

Baltz DM, Rakocinski C, Fleeger JW (1993) Microhabitat use by marsh-edge fishes in a Louisiana estuary. Environ Biol Fish 36:109-126

Baltz DM, Fleeger JW, Rakocinski CF, McCall JN (1998) Food, density, and microhabitat: Factors affecting growth and recruitment potential of juvenile saltmarsh fishes. Environ Biol Fish 53:89-103

Barshaw DE, Able KW, Heck KL (1994) Salt marsh peat reefs as protection for postlarval lobsters Homarus americanus from fish and crab predators-comparisons with other substrates. Mar Ecol Prog Ser 106:203-206

Bartholomew A, Diaz RJ, Cicchetti G (2000) New dimensionless indices of structural habitat complexity: predicted and actual effects on a predator's foraging success. Mar Ecol Prog Ser 206:45-58

Beck MW, Heck KL Jr, Able K, Childers D and 9 others (2001) The identification, conservation, and management of estuarine and marine nurseries for fish and invertebrates. Bioscience 51:633-641

Boesch DF, Turner RE (1984) Dependence of fishery species on salt marshes: the role of food and refuge. Estuaries 7 : $460-468$ 
Buckley L, Caldarone E, Ong TL (1999) RNA-DNA ratio and other nucleic acid-based indicators for growth and condition of marine fishes. Hydrobiologia 401:265-277

Bulger AJ, Hayden BP, Monaco ME, Nelson DM, McCormickray MG (1993) Biologically-based estuarine salinity zones derived from a multivariate analysis. Estuaries 16:311-322

Campana SE (1999) Chemistry and composition of fish otoliths: pathways, mechanisms and applications. Mar Ecol Prog Ser 188:263-297

Castellanos DL, Rozas LP (2001) Nekton use of submerged aquatic vegetation, marsh, and shallow unvegetated bottom in the Atchafalaya River Delta, a Louisiana tidal freshwater ecosystem. Estuaries 24:184-197

Cattrijsse A, Makwaia ES, Dankwa HR, Hamerlynck O, Hemminga MA (1994) Nekton communities of an intertidal creek of a European estuarine brackish marsh. Mar Ecol Prog Ser 109:195-208

Cattrijsse A, Dankwa HR, Mees J (1997) Nursery function of an estuarine tidal marsh for the brown shrimp Crangon crangon. J Sea Res 38:109-121

Chamberlain RH, Barnhart RA (1993) Early use by fish of a mitigation salt marsh, Humboldt Bay, California. Estuaries 16:769-783

Chapman VJ (1960) Salt marshes and salt deserts of the world. Interscience Publishers, New York

Chesney EJ, Baltz DM, Thomas RG (2000) Louisiana estuarine and coastal fisheries and habitats: perspectives from a fish's eye view. Ecol Appl 10:350-366

Cicchetti G (1998) Habitat use, secondary production, and trophic export by salt marsh nekton in shallow waters. $\mathrm{PhD}$ thesis, The College of William and Mary, Williamsburg, VA

Cicchetti G, Diaz RJ (2000) Types of salt marsh edge and export of trophic energy from marshes to deeper habitats. In: Weinstein MP, Kreeger DA (eds) Concepts and controversies in tidal marsh ecology. Kluwer Academic Publishers, Dordrecht, p 515-542

Clark RD, Minello TJ, Christensen JD, Caldwell PA, Monaco ME, Matthews GA (1999) Modeling nekton habitat use in Galveston Bay, Texas: An approach to define essential fish habitat (EFH). National Ocean Service Biogeography Program Technical Report Number 17, Silver Spring, MD

Connolly RM (1999) Saltmarsh as habitat for fish and nektonic crustaceans: challenges in sampling designs and methods. Aust J Ecol 24:422-430

Costa MJ, Costa JL, Dealmeida PR, Assis CA (1994) Do eel grass beds and salt marsh borders act as preferential nurseries and spawning grounds for fish-an example of the Mira Estuary in Portugal. Ecol Eng 3:187-195

Courtney AJ, Die DJ, Holmes MJ (1994) Discriminating populations of the eastern king prawn, Penaeus plebejus, from different estuaries using ICP-MS trace element analysis. At Spectrosc 15:1-6

Craig JK, Crowder LB (2000) Factors influencing habitat selection in fishes with a review of marsh ecosystems. In: Weinstein MP, Kreeger DA (eds) Concepts and controversies in tidal marsh ecology. Kluwer Academic Publishers, Dordrecht, p 241-266

Curran MC, Able KW (1998) The value of tethering fishes (winter flounder and tautog) as a tool for assessing predation rates. Mar Ecol Prog Ser 163:45-51

Currin CA, Newell SY, Paerl HW (1995) The role of standing dead Spartina alterniflora and benthic microalgae in salt marsh food webs: considerations based on multiple stable isotope analysis. Mar Ecol Prog Ser 121:99-116

Deegan LA (1990) Effects of estuarine environmental conditions on population dynamics of young-of-the-year gulf menhaden. Mar Ecol Prog Ser 68:195-205
Deegan LA (1993) Nutrient and energy transport between estuaries and coastal marine ecosystems by fish migration. Can J Fish Aquat Sci 50:74-79

Deegan LA, Garritt RH (1997) Evidence for spatial variability in estuarine food webs. Mar Ecol Prog Ser 147:31-47

Deegan LA, Thompson BA (1985) The ecology of fish communities in the Mississippi River deltaic plain. In: YanezArancibia A (ed) Fish community ecology in estuaries and coastal lagoons: towards an ecosystem integration. UNAM Press, Mexico City, p 35-56

Deegan LA, Hughes JE, Rountree RA (2000) Salt marsh ecosystem support of marine transient species. In: Weinstein MP, Kreeger DA (eds) Concepts and controversies in tidal marsh ecology. Kluwer Academic Publishers, Dordrecht, p 333-365

Desmond JS, Zedler JB, Williams GD (2000) Fish use of tidal creek habitats in 2 southern California salt marshes. Ecol Eng 14:233-252

Drake P, Arias AM (1991) Composition and seasonal fluctuations of the ichthyoplankton community in a shallow tidal channel of Cadiz Bay (SW Spain). J Fish Biol 39:245-263

Efron B (1987) Better bootstrap confidence-intervals. J Am Statist Assoc 82:171-185

Epifanio CE (1995) Transport of blue crab (Callinectes sapidus) larvae in the waters off Mid-Atlantic states. Bull Mar Sci 57:713-725

Ford TB, St. Amant LS (1971) Management guidelines for predicting brown shrimp, Penaeus aztecus, production in Louisiana. Proc Gulf Caribb Fish Inst 23:149-161

Fredette TJ, Diaz RJ, Van Montfrans J, Orth RJ (1990) Secondary production within a seagrass bed (Zostera marina and Ruppia maritima) in lower Chesapeake Bay. Estuaries 13:431-440

Fry B, Sherr EB (1984) $\delta^{13} \mathrm{C}$ measurements as indicators of carbon flow in marine and freshwater ecosystems. Contrib Mar Sci 27:13-48

Gillanders BM, Kingsford MJ (2000) Elemental fingerprints of otoliths of fish may distinguish estuarine 'nursery' habitats. Mar Ecol Prog Ser 201:273-286

Gillanders BM, Able KW, Brown JA, Eggleston DB, Sheridan PF (2003) Evidence of connectivity between juvenile and adult habitats for mobile marine fauna: an important component of nurseries. Mar Ecol Prog Ser (in press)

Goldberg R, Phelan B, Pereira J, Hagan S and 5 others (2002) Variability in habitat use by young-of-the-year winter flounder, Pseudopleuronectes americanus, in three northeastern U.S. estuaries. Estuaries 25:215-226

Guindon KY, Miller JM (1995) Growth potential of juvenile southern flounder, Paralichthys lethostigma, in low salinity nursery areas of Pamlico Sound, North Carolina, USA. Neth J Sea Res 34:89-100

Havens KJ, Varnell LM, Bradshaw JG (1995) An assessment of ecological conditions in a constructed tidal marsh and 2 natural reference tidal marshes in coastal Virginia. Ecol Eng 4:117-141

Heck KL Jr, Nadeau DA, Thomas R (1997) The nursery role of seagrass beds. Gulf Mex Sci 15:50-54

Heck KL Jr, Coen LD, Morgan SG (2001) Pre- and post-settlement factors as determinants of juvenile blue crab (Callinectes sapidus) abundance: results from the north-central Gulf of Mexico. Mar Ecol Prog Ser 222:163-176

Heck KL Jr, Coen LD, Morgan SG, Zimmer-Faust RK (1994) Recruitment and habitat utilization by the blue crab Callinectes sapidus: the importance of juvenile nursery habitats to the fishery. Final report for Marine Fisheries Imitative (MARFIN). National Marine Fisheries Service, St Petersburg, FL 
Hedges LV, Olkin I (1985) Statistical methods for metaanalysis. Academic Press, New York

Herke WH, Knudsen EE, Knudsen PA, Rogers BD (1992) Effects of semi-impoundment of Louisiana marsh on fish and crustacean nursery use and export. N Am J Fish Manag 12:151-160

Howe JC, Wallace RK (2000) Relative abundance of postlarval and juvenile penaeid shrimps in submerged aquatic vegetation and emergent marsh habitats. Gulf Mex Sci 2000:130-137

Howe JC, Wallace RK, Rikard FS (1999) Habitat utilization by postlarval and juvenile penaeid shrimps in Mobile Bay, Alabama. Estuaries 22:971-979

Hughes JE, Deegan LA, Peterson BJ, Holmes RM, Fry B (2000) Nitrogen flow through the food web in the oligohaline zone of a new England estuary. Ecology 81:433-452

Irlandi EA, Crawford MK (1997) Habitat linkages: The effect of intertidal saltmarshes and adjacent subtidal habitats on abundance, movement, and growth of an estuarine fish. Oecologia 110:222-230

Kneib RT (1984) Patterns in the utilization of the intertidal salt marsh by larvae and juveniles of Fundulus heteroclitus (Linnaeus) and Fundulus luciae (Baird). J Exp Mar Biol Ecol 83:41-51

Kneib RT (1997a) Early life stages of resident nekton in intertidal marshes. Estuaries 20:214-230

Kneib RT (1997b) The role of tidal marshes in the ecology of estuarine nekton. Oceanogr Mar Biol Annu Rev 35: $163-220$

Kneib RT (2000) Salt marsh ecoscapes and production transfers by estuarine nekton in the southeastern United States. In: Weinstein MP, Kreeger DA (eds) Concepts and controversies in tidal marsh ecology. Kluwer Academic Publishers, Dordrecht, p 267-291

Kneib RT, Scheele CEH (2000) Does tethering of mobile prey measure relative predation potential? An empirical test using mummichogs and grass shrimp. Mar Ecol Prog Ser 198:181-190

Kneib RT, Wagner SL (1994) Nekton use of vegetated marsh habitats at different stages of tidal inundation. Mar Ecol Prog Ser 106:227-238

Knudsen EE, Herke WH, Mackler JM (1977) The growth rate of marked juvenile brown shrimp, Penaeus aztecus, in a semi-impounded Louisiana coastal marsh. Proc Gulf Caribb Fish Inst 29:144-159

Kwak TJ, Zedler JB (1997) Food web analysis of southern California coastal wetlands using multiple stable isotopes. Oecologia 110:262-277

Laffaille P, Brosse S, Feunteun E, Baisez A, Lefeuvre JC (1998) Role of fish communities in particulate organic matter fluxes between salt marshes and coastal marine waters in the Mont Saint-Michel Bay. Hydrobiologia 374:121-133

Madon SP, Williams GD, West JM, Zedler JB (2001) The importance of marsh access to growth of the California killifish, Fundulus parvipinnis, evaluated through bioenergetics modeling. Ecol Model 135:149-165

Mathieson S, Cattrijsse A, Costa MJ, Drake P, Elliot M, Gardner J, Marchand J (2000) Fish assemblages of European tidal marshes: a comparison based on species, families and functional guilds. Mar Ecol Prog Ser 204:225-242

Mense DJ, Wenner EL (1989) Distribution and abundance of early life history stages of the blue crab, Callinectes sapidus, in tidal marsh creeks near Charleston, South Carolina. Estuaries 12:157-168

Micheli F (1996) Predation intensity in estuarine soft bottoms: between-habitat comparisons and experimental artifacts. Mar Ecol Prog Ser 141:295-302
Micheli F, Peterson CH (1999) Estuarine vegetated habitats as corridors for predator movements. Conserv Biol 13: 869-881

Miller JM, Neill WH, Duchon KA, Ross SW (2000) Ecophysiological determinants of secondary production in salt marshes: a simulation study. In: Weinstein MP, Kreeger DA (eds) Concepts and controversies in tidal marsh ecology. Kluwer Academic Publishers, Dordrecht, p 315-332

Minello TJ (1993) Chronographic tethering: a technique for measuring prey survival time and testing predation pressure in aquatic habitats. Mar Ecol Prog Ser 101:99-104

Minello TJ (1999) Nekton densities in shallow estuarine habitats of Texas and Louisiana and the identification of essential fish habitat. In: Benaka LR (ed) Fish habitat: Essential fish habitat and rehabilitation. The American Fisheries Society, Bethesda, MD, p 43-75

Minello TJ, Rozas LP (2002) Nekton populations in Gulf Coast wetlands: fine-scale spatial distributions, landscape patterns, and restoration implications. Ecol Appl 12:441-455

Minello TJ, Webb JW (1997) Use of natural and created Spartina alterniflora salt marshes by fishery species and other aquatic fauna in Galveston Bay, Texas, USA. Mar Ecol Prog Ser 151:165-179

Minello TJ, Zimmerman RJ (1983) Fish predation on juvenile brown shrimp, Penaeus aztecus Ives: The effect of simulated Spartina structure on predation rates. J Exp Mar Biol Ecol 72:211-231

Minello TJ, Zimmerman RJ (1985) Differential selection for vegetative structure between juvenile brown shrimp (Penaeus aztecus) and white shrimp (P. setiferus), and implications in predator-prey relationships. Estuar Coast Shelf Sci 20:707-716

Minello TJ, Zimmerman RJ (1991) The role of estuarine habitats in regulating growth and survival of juvenile penaeid shrimp. In: DeLoach P, Dougherty WJ, Davidson MA (eds) Frontiers in shrimp research. Elsevier Science Publishers, Amsterdam, p 1-16

Minello TJ, Zimmerman RJ, Martinez EX (1989) Mortality of young brown shrimp Penaeus aztecus in estuarine nurseries. Trans Am Fish Soc 118:693-708

Minello TJ, Webb JW, Zimmerman RJ, Wooten RB, Martinez JL, Baumer TJ, Pattillo MC (1991) Habitat availability and utilization by benthos and nekton in Hall's Lake and West Galveston Bay. US Dept Commerce NOAA Tech Mem, NMFS-SEFC-275, Silverspring, MD

Morgan SG, Zimmerfaust RK, Heck KL, Coen LD (1996) Population regulation of blue crabs Callinectes sapidus in the northern Gulf of Mexico: postlarval supply. Mar Ecol Prog Ser 133:73-88

Moy LD, Levin LA (1991) Are Spartina marshes a replaceable resource? A functional approach to evaluation of marsh creation efforts. Estuaries 14:1-16

Nelson WG, Bonsdorff E (1990) Fish predation and habitat complexity: are complexity thresholds real? J Exp Mar Biol Ecol 141:183-94

Nixon SW, Oviatt CA (1973) Ecology of a New England salt marsh. Ecol Monogr 43:463-498

Odum EP (1971) Fundamentals of ecology, 3rd edn. WB Saunders Company, Philadelphia

Olmi EJ (1995) Ingress of blue crab megalopae in the York River, Virginia, 1987-1989. Bull Mar Sci 57:753-780

Orth RJ, Van Montfrans J (1987) Utilization of a seagrass meadow and tidal marsh creek by blue crabs Callinectes sapidus. I. Seasonal and annual variations in abundance with emphasis on post-settlement juveniles. Mar Ecol Prog Ser 41:283-294

Paterson AW, Whitfield AK (1996) The fishes associated with 
an intertidal salt marsh creek in the Kariega Estuary, South Africa. Trans R Soc S Afr 51:195-218

Perez Farfante I, Kensley B (1997) Penaeoid and sergestoid shrimps and prawns of the world; keys and diagnoses for the families and genera. Mem Mus Natl Hist Nat 175: 233

Peters DS, Cross FA (1992) What is coastal fish habitat? In: Stroud RH (ed) Stemming the tide of coastal fish habitat loss. National Coalition for Marine Conservation, Savannah, p 17-22

Peterson CH, Black R (1994) An experimentalist's challenge - when artifacts of intervention interact with treatments. Mar Ecol Prog Ser 111:289-297

Petrik R, Levin PS, Stunz GW, Malone J (1999) Recruitment of Atlantic croaker, Micropogonias undulatus: Do post settlement processes disrupt or reinforce initial patterns of settlement? Fish Bull 97:954-961

Phelan BA, Goldberg R, Bejda AJ, Pereira J and 5 others (2000) Estuarine and habitat-related differences in growth rates of young-of-the-year winter flounder (Pseudopleuronectes americanus) and tautog (Tautoga onitis) in three northeastern US estuaries. J Exp Mar Biol Ecol 247:1-28

Ricklefs RE (1973) Ecology. Chiron Press, Newton, MA

Rogers BD, Shaw RF, Herke WH, Blanchet RH (1993) Recruitment of postlarval and juvenile brown shrimp (Penaeus aztecus Ives) from offshore to estuarine waters of the northwestern Gulf of Mexico. Estuar Coast Shelf Sci 36: 377-394

Rogers DR, Rogers BD, Herke WH (1994) Structural marsh management effects on coastal fishes and crustaceans. Environ Manag 18:351-369

Rooker JR, Holt GJ, Holt SA (1997) Condition of larval and juvenile red drum (Sciaenops ocellatus) from estuarine nursery habitats. Mar Biol 127:387-394

Rooker JR, Holt SA, Holt GJ, Fuiman LA (1999) Spatial and temporal variability in growth, mortality, and recruitment potential of postsettlement red drum, Sciaenops ocellatus, in a subtropical estuary. Fish Bull 97:581-590

Rosenberg MS, Adams DC, Gurevitch J (2000) MetaWin: statistical software for meta-analysis version 2.0. Sinauer Associates, Sunderland, MA, p 128

Rothlisberg PC, Church JA, Forbes MG (1983) Modelling the advection of vertically migrating shrimp larvae. J Mar Res 41:511-538

Rountree RA, Able KW (1992) Fauna of polyhaline subtidal marsh creeks in southern New Jersey-composition, abundance and biomass. Estuaries 15:171-185

Rozas LP (1993) Nekton use of salt marshes of the Southeast region of the United States. In: Magoon O, Wilson WS, Converse H, Tobin LT (eds) Coastal zone 1993, Vol 2. Proc 8th Symp Coast Ocean Manag. American Society of Civil Engineers, New York, p 528-537

Rozas LP (1995) Hydroperiod and its influence on nekton use of the salt marsh: a pulsing ecosystem. Estuaries 18: $579-590$

Rozas LP, LaSalle MW (1990) A comparison of the diets of gulf killifish, Fundulus grandis Baird and Girard, entering and leaving a Mississippi brackish marsh. Estuaries 13(3): 332-336

Rozas LP, Minello TJ (1997) Estimating densities of small fishes and decapod crustaceans in shallow estuarine habitats: A review of sampling design with focus on gear selection. Estuaries 20:199-213

Rozas LP, Minello TJ (1998) Nekton use of salt marsh, seagrass, and nonvegetated habitats in a South Texas (USA) estuary. Bull Mar Sci 63:481-501

Rozas LP, Minello TJ (1999) Effects of structural marsh man- agement on fishery species and other nekton before and during a spring drawdown. Wetl Ecol Manag 7:121-139

Rozas LP, Odum WE (1987) The role of submerged aquatic vegetation in influencing the abundance of nekton on contiguous tidal fresh-water marshes. J Exp Mar Biol Ecol 114:289-300

Rozas LP, Reed DJ (1993) Nekton use of marsh-surface habitats in Louisiana (USA) deltaic salt marshes undergoing submergence. Mar Ecol Prog Ser 96:147-157

Rozas LP, Zimmerman RJ (2000) Small-scale patterns of nekton use among marsh and adjacent shallow nonvegetated areas of the Galveston Bay estuary, Texas (USA). Mar Ecol Prog Ser 193:217-239

Ryer CH, Van Montfrans J, Moody KE (1997) Cannibalism, refugia and the molting blue crab. Mar Ecol Prog Ser 147: $77-85$

Secor DH, Zdanowicz VS (1998) Otolith microconstituent analysis of juvenile bluefin tuna (Thunnus thynnus) from the Mediterranean Sea and Pacific Ocean. Fish Res 36: 251-256

Shirley MA, Hines AH, Wolcott TG (1990) Adaptive significance of habitat selection by molting adult blue crabs Callinectes sapidus (Rathbun) within a subestuary of central Chesapeake Bay. J Exp Mar Biol Ecol 140:107-119

Shreffler DK, Simenstad CA, Thom RM (1990) Temporary residence by juvenile salmon in a restored estuarine wetland. Can J Fish Aquat Sci 47:2079-2084

Simenstad CA, Hood WG, Thom RM, Levy DA, Bottom DL (2000) Landscape structure and scale constraints on restoring estuarine wetlands for Pacific Coast juvenile fishes. In: Weinstein MP, Kreeger DA (eds) Concepts and controversies in tidal marsh ecology. Kluwer Academic Publishers, Dordrecht, p 597-630

Sogard SM, Able KW (1991) A comparison of eelgrass, sea lettuce macroalgae, and marsh creeks as habitats for epibenthic fishes and decapods. Estuar Coast Shelf Sci 33: 501-519

Stunz GW, Minello TJ (2001) Habitat-related predation on juvenile wild-caught and hatchery-reared red drum Sciaenops ocellatus (Linnaeus). J Exp Mar Biol Ecol 260: $13-25$

Stunz GW, Minello TJ, Levin PS (2002a) Growth of newly settled red drum Sciaenops ocellatus in different estuarine habitat types. Mar Ecol Prog Ser 238:227-236

Stunz GW, Minello TJ, Levin PS (2002b) A comparison of early juvenile red drum densities among various habitat types in Galveston Bay, Texas. Estuaries 25:76-85

Teal JM (1962) Energy flow in the salt marsh ecosystem of Georgia. Ecology 43:614-624

Thomas BE, Connolly RM (2001) Fish use of subtropical saltmarshes in Queensland, Australia: relationships with vegetation, water depth and distance onto the marsh. Mar Ecol Prog Ser 209:275-288

Thomas JL (1989) A comparative evaluation of Halodule wrightii Aschers, Spartina alterniflora Loisel and bare sand as nursery habitats for juvenile Callinectes sapidus (Rathbun). MSc thesis, Texas A\&M University, College Station, TX

Thomas JL, Zimmerman RJ, Minello TJ (1990) Abundance patterns of juvenile blue crabs (Callinectes sapidus) in nursery habitats of 2 Texas bays. Bull Mar Sci 46:115-125

Thresher RE (1999) Elemental composition of otoliths as a stock delineator in fishes. Fish Res 43:165-204

Topping J (1962) Errors of observation and their treatment. Institute of Physics, London, p 119

Turner RE (1977) Intertidal vegetation and commercial yields of penaeid shrimp. Trans Am Fish Soc 106:411-416 
Turner RE (1992) Coastal wetlands and penaeid shrimp habitat. In: Stroud RH (ed) Stemming the tide of coastal fish habitat loss. National Coalition for Marine Conservation, Savannah, p 97-104

Turner RE, Boesch DF (1988) Aquatic animal production and wetland relationships: insights gleaned following wetland loss or gain. In: Hook DD (ed) The ecology and management of wetlands. Timber Press, Portland, p 25-39

Underwood AJ (1997) Experiments in ecology: their logical design and interpretation using analysis of variance. Cambridge University Press, Cambridge

Vila Y, Medina A, Megina C, Ramos F, Sobrino I (2000) Quantification of the age-pigment lipofuscin in brains of known-age, pond-reared prawns Penaeus japonicus (Crustacea, Decapoda). J Exp Zool 286:120-130

Wainright SA, Weinstein MP, Able KW, Currin CA (2000) Relative importance of benthic microalgae, phytoplankton and detritus of smooth cordgrass (Spartina) and the common reed (Phragmites) to brackish marsh food webs. Mar Ecol Prog Ser 200:77-91

Webb SR, Kneib RT (2002) Abundance and distribution of juvenile white shrimp Litopenaeus setiferus within a tidal marsh landscape. Mar Ecol Prog Ser 232:213-223

Weinstein MP (ed) (1988) Larval fish and shellfish transport through coastal inlets. Am Fish Soc Symp 3:1-3

Weinstein MP, Brooks HA (1983) Comparative ecology of nekton residing in a tidal creek and adjacent seagrass meadow: community composition and structure. Mar Ecol Prog Ser 12:15-27

Weinstein MP, Walters MP (1981) Growth, survival and production in young-of-year populations of Leiostomus xanthurus Lacepede residing in tidal creeks. Estuaries 4: 185-197

Weinstein MP, Weiss SL, Hodson RG, Gerry LR (1980a) Retention of postlarval fishes in an intensively flushed tidal estuary, Cape Fear, North Carolina. Fish Bull 78: 419-436

Weinstein MP, Weiss SL, Walters MF (1980b) Multiple determinants of community structure in shallow marsh habitats, Cape Fear River estuary, North Carolina, USA. Mar Biol 58:227-243

Weinstein MP, Scott L, O'Neil SP, Siegfried RC, Szedlmayer ST (1984) Population dynamics of spot, Leiostomus xanthurus, in polyhaline tidal creeks of the York River Estuary, Virginia. Estuaries 7:444-450

Weinstein MP, Litvin SV, Bosley KI, Fuller CM, Wainright SC (2000) The role of tidal salt marsh as an energy source for juvenile marine transient finfishes: a stable isotope approach. Trans Am Fish Soc 129:797-810

Wenner E, Knott D, Blanton J, Barans C, Amft J (1998) Roles of tidal and wind-generated currents in transporting white shrimp (Penaeus setiferus) postlarvae through a South Carolina (USA) inlet. J Plankton Res 20:2333-2356

Westerman M, Holt G, DiMichele L (1999) Quantitative assay of cyclin-dependent kinase activity as a sensitive marker of cell proliferation in marine teleost larvae. Mar Biotechnol 1:297-310

Whaley SD (1997) The effects of marsh edge and surface elevation on the distribution of salt marsh infauna and prey availability for nekton predators. MSc thesis, Texas A\&M University, College Station, TX

Whitaker RH, Levin SA (1975) Introduction. In: Whitaker RH, Levin SA (eds) Niche; theory and application. Benchmark papers in ecology No. 3. Dowden, Hutchinson, and Ross, Stroudsburg, PA, p 448

Editorial responsibility: Otto Kinne (Editor), Oldendorf/Luhe, Germany
Whitaker RH, Levin SA, Root RB (1973) Niche, habitat, and ecotope. Am Nat 107:321-338

Whitfield AK (1994) Abundance of larval and 0+ juvenile marine fishes in the lower reaches of 3 southern African estuaries with differing freshwater inputs. Mar Ecol Prog Ser 105:257-267

Wilson KA, Able KW, Heck KL (1990a) Predation rates on juvenile blue crabs in estuarine nursery habitats: evidence for the importance of macroalgae (Ulva lactuca). Mar Ecol Prog Ser 58:243-251

Wilson KA, Able KW, Heck KL (1990b) Habitat use by juvenile blue crabs: a comparison among habitats in southern New Jersey. Bull Mar Sci 46:105-114

Zimmerman RJ (1988) A survey and assessment of usage of a salt marsh at Grand Isle, Louisiana, by estuarine aquatic fauna. Report to the Environmental Protection Agency, Region VI, Dallas, TX. National Marine Fisheries Service Galveston Laboratory, Galveston, TX

Zimmerman RJ, Minello TJ, Klima EF, Baumer T, Pattillo M, Pattillo-Costiglione M (1992) Site selection for beneficial use of dredge material through marsh creation in Galveston Bay. Final report to the US Army Corps of Engineers, Galveston District and the Port of Houston Authority. National Marine Fisheries Service Galveston Laboratory, Galveston, TX, p 174

Zimmerman RJ, Minello TJ (1984a) Fishery habitat requirements: Utilization of nursery habitats by juvenile penaeid shrimp in a Gulf of Mexico salt marsh. In: Copeland BJ, Hart K, Davis N , Friday S (eds) Research for managing the nation's estuaries. University of North Carolina Sea Grant College Publication UNC-SG-84-08, p 371-383

Zimmerman RJ, Minello TJ (1984b) Densities of Penaeus aztecus, $P$. setiferus and other natant macrofauna in a Texas salt marsh. Estuaries 7:421-433

Zimmerman RJ, Minello TJ, Zamora G (1984) Selection of vegetated habitat by brown shrimp, Penaeus aztecus, in a Galveston Bay salt marsh. Fish Bull 82:325-336

Zimmerman RJ, Minello TJ, Baumer T, Castiglione M (1989) Oyster reef as habitat for estuarine macrofauna. US Department of Commerce NOAA Tech Mem NMFS-SEFC249, Silver Spring, MD, p 16

Zimmerman RJ, Minello TJ, Baumer TJ, Castiglione MC (1990a) Utilization of nursery habitats in San Antonio Bay in relation to annual salinity variation. Final report to Texas Parks and Wildlife Department and the Texas Water Development Board. National Marine Fisheries Service Galveston Laboratory, Galveston, TX, p 56

Zimmerman RJ, Minello TJ, Castiglione M, Smith D (1990b) Utilization of marsh and associated habitats along a salinity gradient in Galveston Bay. US Dept Commerce NOAA Tech Mem, NMFS-SEFC-250, Silver Spring, MD

Zimmerman RJ, Minello TJ, Smith D, Castiglione M (1990c) The use of Juncus and Spartina marshes by fisheries species in Lavaca Bay, Texas, with reference to effects of floods. US Dept Commerce NOAA Tech Mem, NMFSSEFC-251, Silver Spring, MD

Zimmerman RJ, Minello TJ, Klima EF, Nance JM (1991) Effects of accelerated sea-level rise on coastal secondary production. In: Bolton HS (ed) Coastal wetlands. The American Society of Civil Engineers, New York, p 110-124

Zimmerman RJ, Minello TJ, Rozas LP (2000) Salt marsh linkages to productivity of penaeid shrimps and blue crabs in the northern Gulf of Mexico. In: Weinstein MP, Kreeger DA (eds) Concepts and controversies in tidal marsh ecology. Kluwer Academic Publishers, Dordrecht, p 293-314

Submitted: January 31, 2002; Accepted: September 17, 2002 Proofs received from author(s): December 12, 2002 